\title{
逆磁場ピンチプラズマにおける閉じ込め研究の現状と 閉じ込め改善モード
}

\author{
平 野 洋一 \\ (電子技術総合研究所)
}

\author{
Recent Confinement Studies and Improved Confinement Modes \\ in Reversed Field Pinch Plasmas
}

\author{
HIRANO Yoichi \\ Electrotechnical Laboratory, Tsukuba 305-8568, Japan
}

(Received 25 Decembcr 1998 / Accepted 1 March 1999)

\begin{abstract}
Recent results of confincment studies and attempts to improve the confinement in reversed field pinch plasmas (RFP) are reviewed. Several scaling studies of RFP energy confinement time are summarized and the values of the confinement time of RFPs are compared with ITER-89P L-mode scaling. A new scaling law recently proposed is also described. Results of transport studies in RFPs are summarized and it is shown that the stochasticity of magnetic field lines caused by the magnetic fluctuations of dynamo action probably plays a dominant role in the core of RFP plasma. Recent Lundquist number scaling study for magnetic fluctuations is also described. Promising experimental and simulation results are introduced which are conducted to improve the RFP confinement. For examples, five-hold improvement of the energy confinement time is obtained in MST by driving the poloidal current in outer region with the pulsed poloidal current drive (PPCD). The increase of poloidal beta up to $20 \%$ is obtained in the Improved High Theta Mode in TPE-1RM20. Improved confinement by a flow shear is also observed in RFPs as in tokamaks and helical systems. Finally experimental and computational results are described which may indicate the bifurcation from the dynamo with multiple helical magnelic fluctuations to that with a single helical fluctuation through the increase of Prandtl number. In the case with a single helical fluctuation. the stochastic region caused by the over-lapping of magnetic islands can be reduced and the confinement degradation by the stochasticity of magnetic field lines may be avoided.
\end{abstract}

\section{Keywords:}

review paper, confinement study, reversed field pinch, magnetic confinement, controlled fusion

\section{1.はじめに}

逆璔堨ビンチ (Reversed Field Pinch, RFP) は核融合 ブラスママの閣じ込めをめざした磁場によるプラズマ閉じ 込め方式の一つであり，トカマクと同じく軸対称内部電 流系トーラスの一貝である. RFPの磁場配位の特徽は, トロイダル磁場の向きがブラスマの中心と外㑡で反転し author's e-mail: yhirano@etl.go.jp
ていることである (Fig. 1 参照).このような磁場配位を取 ることにより小さな外部トロイタル磁場（トカマクの1/100 以下）で大きなプラズマ電流を安定に流すことが可能とな ク，この大きなプラスマ電流を用いた强力な抵抗加熱を利 用して高温・高密度のプラズマの閉し込めを, 尚価な追加 熱なしで効率よく実現することができる[1-3]. 


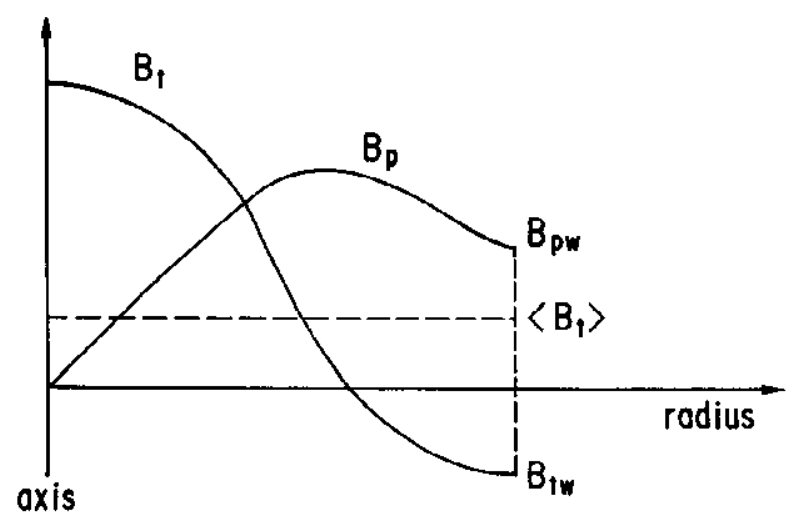

Fig. 1 Schematic drawing of the configuration of magnetic field in a RFP.

・般的に言って，核融命为门実現には，第一壁ャブラ ンケット構造材の巾性子壁年荷が重要なキーポイントで あることはよく知られて拉り，そ心ため，中性了壁負荷 に耐える材料の䦕発が様尔方向から実施されている。

しかしながら，灿の全寿命中の使用が叮能で取り替え。不 要な, 高い酎性在持つ材料の開発にはかなりの期間を要 するものと予想き扎る。したがって，このような新材料 を想定せず，10 MW 住 $\mathrm{m}^{2}$ 程度以卜の材料を用いた炉

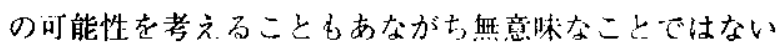

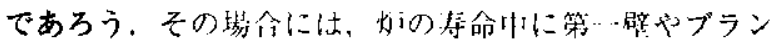
ケット棈造材をかなりす頻度で取り替えるこ上が必要と

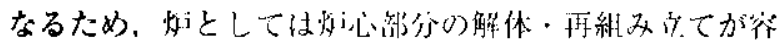

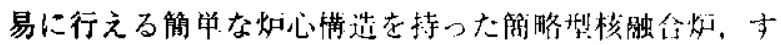
なわち, Simple Fusion Reactorであることが望ましい. トーラス型の核融命䴓で，装置の分解を困難にする早 大の原因は，小㓅方们に卷きついた超伀導コイルである と考えられる。先に述べたようにRFPは，外部卜ロイ タル磁場が弱くても，大きなブラズマ電流を持った MHD 的に妢是な高ベータプラズマの保持が可能である ため，恦を想定した時でもトロイダルコイルには常伝導 コイルの使用が叮能である。したがって、コイル系全体 を赤道面付近で上下に 2 分割にすることができ，2 分割 後にコイルの上側部分を取り外し，次いで真空察器を含 んだ妸心部分を一体として取り山して，あらかじめ用意 したスぺアとの交換を短時間で行うという，再組み立 て・再稼謿を容易に行う方法を考えることができる。 らに、RFPに強力なプラズマ電流によるオーミック イグニッションの可能性, 外部卜ロイダル磁場が弱いこ とからくる広いタイバー夕公の設惪による熱負荷の分散 等の利点を持って扔り, Simple Fusion Reactor として の高いポテンシャルを持っている.
頻筿な灿心部の取り替えを想定したトーラス型の奸形 式は最初 OHTE [4]で提案された. OHTEと RFPとど ちらが有利であるかは，ベー夕値等の閉じ込め性能と工 学的な観点を総合的に比較する必要があるが, OHTE と比ベてヘリカルコイルが不要であることから RFP の 方がより構造が簡単であるということはできる.

一方これら RFPの㥫としてのポテンシャルも，十 分なプラズマ閉じ这め性能が奏現しない限りは，絵に描 いた餅となってしまう. 現在, RFPの実験では, $1 \mathrm{keV}$ 近くの高電子温度 [5]，20\%程度の高ポロイダルベータ $[6.7], 100 \mathrm{~ms}$ 以上のプラズマ保持時間 [8], $5 \mathrm{~ms}$ 程度 のエネルギー閉じ込め時間 [9] 等を，0.2 T以下の低磁 場で達成するなど, 多くの成果を得てはいるが, 上記の Simple Fusion Reactor としてのポテンシャルを活かす のに才分な閉じ迄め性能が実現されているとは言いがた い.すなわち，同规模のトカマク等の装置に比べて，1 分な閉じ达め時間が得られない，言い換えると，プラズ マの損失が大きい点が最大の問題である.

しかしながら，最近，RFPにおいて，ブラズマ損失 のメカニズムの実験的解明が進むとともに，プラズマの 閉じ这めが改善されるいくつかの運転モードが見いださ れてきた。また，理諭，ならびにシミュレーションによ ク，RFP のプラズマ閉じ込めの向上に有効であると考 えられる手法が，いくつか提案されてきており，今後の RFPの研究の進展に期待がもてる状況が現れつつある.

このレビューでは, まず最初にRFPの閉じ込めの研 究の現状を示し, 損失の原因となっているプラズマの輸 送現象のメカニズムについて述べた後，閉じ込め改善を めざした実験とその成果を示す，さらにこれらの実験に 基つくく将来の展望について紹介してまとめとする.

\section{RFP におけるプラズマ閉じ込めの現状}

\subsection{RFP の的じ远め比例則}

\section{(1)ベータ侸一定則}

RFPにおけるプラズマ閉じ込めに関しては，大きく 分けて二通りの考え方がある。一つは, Connor と Taylorによって示された理論に基づき[10]，RFPの閉 し込めは圧力駆動型の抵抗性不安定性の発生によって決 まるべー夕限界值で规定されるというもので，ベー夕值 一定則と呼ばれる。ベー夕限界值は, Connor \& Taylor によれば， $\left(m_{\mathrm{e}} / M_{\mathrm{i}}\right)^{1 / 6} \sim 25 \%$ あるいは Bhattacharjee 等 $[11] に よ れ は ゙ ，\left(m_{\mathrm{e}} / M_{\mathrm{i}}\right)^{1 / 4} \sim 13 \%$, と違いはあるもの の, $10 \%$ 程度以上の高ベータブラズマの閉じ迄めの可 能性を示すものである。 
RFPでは，ナ゙ラズマ閉じ込めに貢献するのは主にナ ラスマ電流の作るポロイタル磁場であるので, ベー夕值 としてもポロイダル磁場に対するべー夕值，すなわち， ポロイダルベータ値が通常用いられる. ポロイダルベー タ值は, ブラズマの平均圧力のブラズマ表面のポロイタ 儿磁場圧力に对する比であり，平均べー夕値の $1.5-3$ 倍程度の大きさである。この解説でもこれ以降は主にポ ロイタルベータ値を用いることとする。

RFPの実験では，ポロイダルベータ値は多くの装置 で，閉じ込めの向上モードでない通常の条件では，おお むね $10 \%$ 前後の値を取る場合が多いことが知られてい る.特にブラズマへの加熱入力密度の高い $\left(>3 \mathrm{MW} / \mathrm{m}^{3}\right)$ 小型の装圈ではこの煩向が強く，プラスママは造加熟の状 態にあると想定され，ポロイタルベータ値は圧力駆動型 の抵抗性不安定性で決まっている可能性が高い，例えば TPE-1RM20では放電条件を適切に選ぶと, 磁場のシア を大きくすることによりポロイダルベータ值を 2 倍に增 加することができるが(後で述べる IHT モード）[6,7]， このことは上記の可能性を強く示唆している，一方，加 熟入力密度の小さな装置では, 圧力駆動型の抵抗性不安 定性ではない別の原内（例えば次に述べる磁場の摇動に よる異常搪散）により，もっと低い值にポロイダルベー 夕俌が制限される場命がある。

ポロイタルベータ値一定の比例則を用い，ブラズマヘ の加熱入力としてジュール加熱のみを考えると，エネル ギー閉じ込め時問の比例則は

$$
\tau_{\mathrm{E}-\text { beta }} \propto a^{-1} n_{\mathrm{e}}^{-1.5} I_{\mathrm{p}}^{3}
$$

と表される，aはブラズマの小半径， $n_{\mathrm{e}}$ は密度， $I_{\mathrm{p}}$ はプ ラズマ電流である[12].

Fig. 2 に各装置で得られた標準的と考えられる条件で のエネルギー閉じ这め時間と, ポロイダルベータ値一定 の此例則を仮定した時の，エネルギー閉じ込め時間を対 比したものを亦す．少々のばらつきはあるものの一応そ れらしい傾向が見られる。この結果はべー夕值一定則が 成り立っていることを示唆しているようにも見える[3]. しかしながら，近磁場ピンチの加熱入力はジュール加熱 だけではなく，後で述べるタイナモ効果による異常加熱 メカニズムが存仕することが知られている[3].この異 常加熟はトロイタル周回電厈の增加（異常成分）として すべての逆磁場ピン千実験で観測されるが，その大きさ は装置に依存している，また，不純物量の增大によって も周回電压は增大するが，その大きさも装㯰ごとのプラ ズマ・壁相互作用の違いによって変化卞る.したがって,

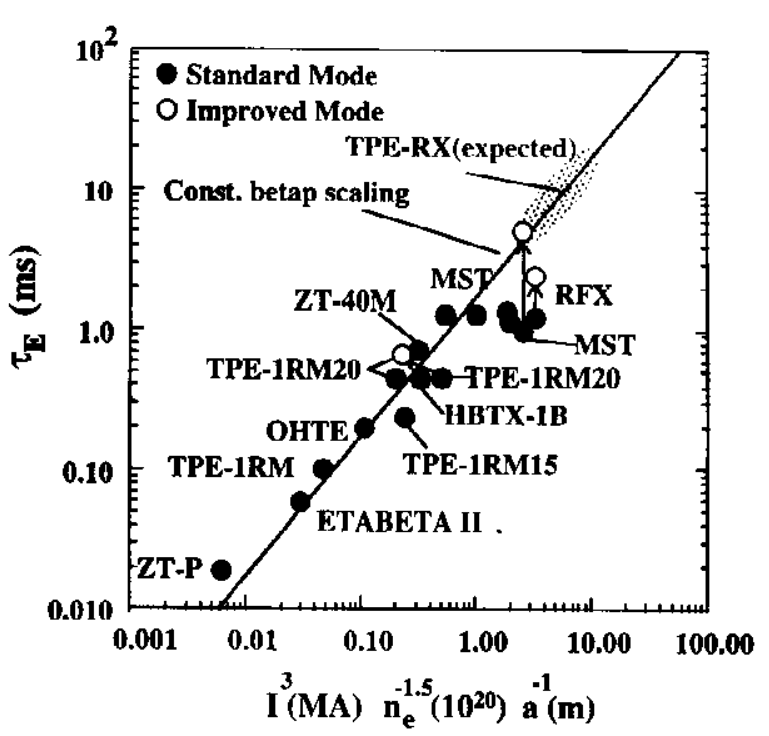

Fig. 2 Constant poloidal beta scaling of the energy confinement time in RFPs.

どちらが周回電圧の増大の原因であるか西者を区別する ことはなかなか難しいが, どちらにせよこの周回電圧の 增大分の違いにより同一のポロイタルベータ值の場合で もエホルギー閉じ込め時間に違いが現れる. Fig.2の TPE-1RM15 と RFX の た の值が小さいのは, ボロイ夕 ルベータ値は小さくないが $(\sim 10 \%)$ ，どちらの原因か はともかく，周回電压の值が期待される値より大きいた めである。

これとは別に, MST で $a^{-1} n^{-1.5} I_{\mathrm{p}}^{3}$ の值が大きいとこ ろでれが小さくなる放電では，ポロイタルル゙ー夕值が 低下して扔り（後で Table 1に示すように6\%，ただし 加熱入力が堌加しているので $\tau_{\mathrm{E}}$ はもっと小さくなる), 後で述べる䦥じ达め收善モードが実現されて始めてポロ イダルベータ值一定のところに復㷌する（閉じ迈的改善 モードではポロイダルベータ值 9\%) [9]．また，逆に TPE-1RM20 の閉じ込め敌善モード（IHT モード）では 約 $20 \%$ のポロイダルベータ值を得ている。これらの結 果は，必ずしもべー夕値一定則が成り立たないことを示 しており，今後実験条件のもっと細かな比較によりべー 夕值一定則が使えるかどうか，もし使えるとしてもどの ような条件の時かを明らかにしていく必要があるであろう。 (2) stochastic magnetic field lineによる抧失

RFPの損失のもうーのの考え方は，プラスママ川の磁 気エネルギーの緩和過程に現れる磁場摇動による磁気面 の乱れが, RFPのプラズマ輖送に主要な役割を果たし ているというものである.

RFP は，その磁場配位の形成・維持に自己反転現象 


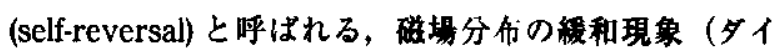
ナモ効果) を用いている，すなわち，RFPにおいては， 境界条件やプラズマ密度等の条件を道当に選択すること により，プラズマは白ら過剩な磁気エネルギーを排仙し て，プラズマ中の磁気エネルギー最小の状態へと緅和す る㖽问老持ち，RFP配位が自発的に形成されることが， 理論と実験の両面から明らかにされている $[13,14]$ ．し かしながら，貶位形成時には有効に動いたダイナモ効果 は，微少とはいえ磁場の摇動を伴うことから，配位形成 後のブラズマ閉じ込め時には磁気面を乱して，プズマ の損失を增大させる.

なお，この磁気エネルギー最小状態の磁場分布は理㮩 的な場合には, 電流密度と磁束密度を $\boldsymbol{J}$ と $\boldsymbol{B}$ とすると, $J=\left(\mu / \mu_{0}\right) \boldsymbol{B}$ ( $\mu$ は定数, $\mu_{0}$ は真空の透磁率) なる無力 磁場配位で表される，円筒プラズマでは磁場配位はベッ セル関数で表され（トロイダル磁場は 0 次の，ポロイタ ル磁場は·次の第·種ベッセル関数となる),ピンチパ ラメータ $\left(\Theta=B_{\mathrm{pw}} /\left\langle B_{1}\right\rangle, B_{\mathrm{pw}} ;\right.$ プラスマ表面のポロ イダル磁場，〈列〉；ブラズマ中の平均トロイダル磁場） と呼ばれる単・のパラメータで状態を決めることができ る $(\mu=2 \Theta / a, a$ はプラズマの小半径).また, 逆転パ ラメータ $\left(F=B_{\mathrm{tw}} /\left\langle B_{\mathrm{t}}\right\rangle, B_{\mathrm{tw}} ;\right.$ プラズマ表面のトロイ タル磁場）と呼ばれるもう一つのパラメータを常入する と、磁気エネルギー最小の完全緩和状態は， $\Theta-F$ 面.上. でテイラー曲線と呼ばれる一本の曲線を描く[13]．一般

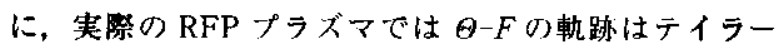
曲線の右㑡に現れ、テイラー曲線に近いほど完全縟和状 態に近いと考えられる。

ダイナモ效果の原理と RFPに抢けるその必要性は, 次の一般化したオームの式を用いてホすことができる。 ブラズマ中の電流密度，Jに対しては，電場を $\boldsymbol{E}$, ブラ ズマの連動を $\boldsymbol{v}$, 磁束密度を $B$, 抵抗率を $\eta$ とすると次 の式が成り立つ。

$$
E+\boldsymbol{v} \times \boldsymbol{B}=\eta J
$$

各々の量が平均成分と摇動成分の和であると考え，上の 式を平均すると

$$
\boldsymbol{E}_{0}+\langle\boldsymbol{v} \times \delta \boldsymbol{B}\rangle=\eta \boldsymbol{J}_{0}
$$

となる．ただし抵抗率の摇動と，平均的なプラズマの運 動はないものと考え。

$\boldsymbol{B}=\boldsymbol{B}_{0}+\delta \boldsymbol{B},\langle\boldsymbol{B}\rangle=\boldsymbol{B}_{0},\langle\delta \boldsymbol{B}\rangle=0$ （他の量についても同 し）とした。ここで準定常状熊を考え，平均磁場（すな わち，平衡磁場）に平行な成分をとると，

$$
E_{01}+\langle\boldsymbol{v} \times \delta B\rangle_{\|}=\eta J_{0 \|}
$$

となる，染定常状態ではポロイタル電場はぜロとなるた め, $E_{0 \mathrm{k}}=E_{0 \mathrm{t}}\left(B_{0 \mathrm{t}} / B_{0}\right)$ と表され，トロイダル磁場の道

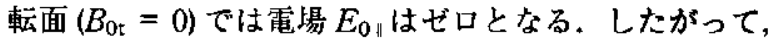
そこではブラズマ電流の定常成分はブラスマの速度と磁 場の搯動の非線形的な相互作用， $\langle\boldsymbol{v} \times \delta \boldsymbol{B}\rangle$ 、により耯持 されることになる。すなわち，ポロイタル電流が，磁場 中の尊電体（この場合はプラズマ）の珪動（审磁誘導） によって維持されているということから，タイナモ（発 電機）效果と呼ばれるわけである.

ダイナモ効果の具体的なメカニズムは, ポロイタル モード数 $m=1$ 拈び $m=0$ のアイデアル, もしくはテ イアリングモードの，非線形的な相互作用により生起す ると考えられている。

RFPの磁場分布では, 安全係数 $q$ は Fig. 3 に示すよ うな分布になり，共鳴条件を満なす高いトロイダルモー ド数 $n$ を持った，多数の $m=1$ モードが存在する。通 常のダイナモ效果の際には，これらの多数の共鸣モード が同時に成長する（ダイナモモード）. Fig. 4 に TPE1RM20の低ピンチパラメー夕領域での, $m=0$ と10 モードの $n$ スペクトルを示すが，中心付近で共鸣する $n=7$ のモードから始まって，nの増加とともに次第に 振幅が減少する多数の $m=1$ モードが存在することが示 されている[15-17].

これらの $m=1$ モードは，各々の共鳴点の回りに磁気 島を形成するが，モードが成長するとこれらの磁気鳥が 重なり合い，磁気面が破培されて，一本の磁力線をたど ることによりプラズマのコア部分から周辺部分まで到達

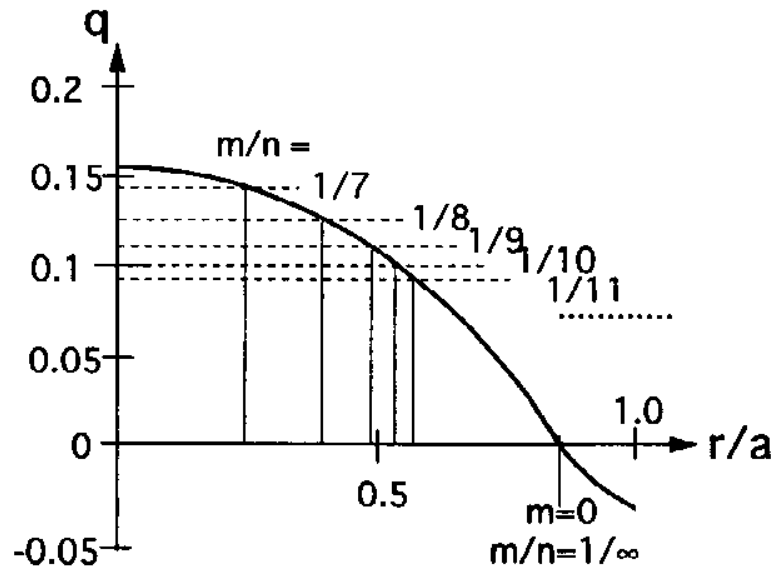

Fig. 3 Schematic drawing of the $q$ (safety factor) profile in a RFP. It is indicated that many resonant $m=1$ modes with different $n$ can exist. 


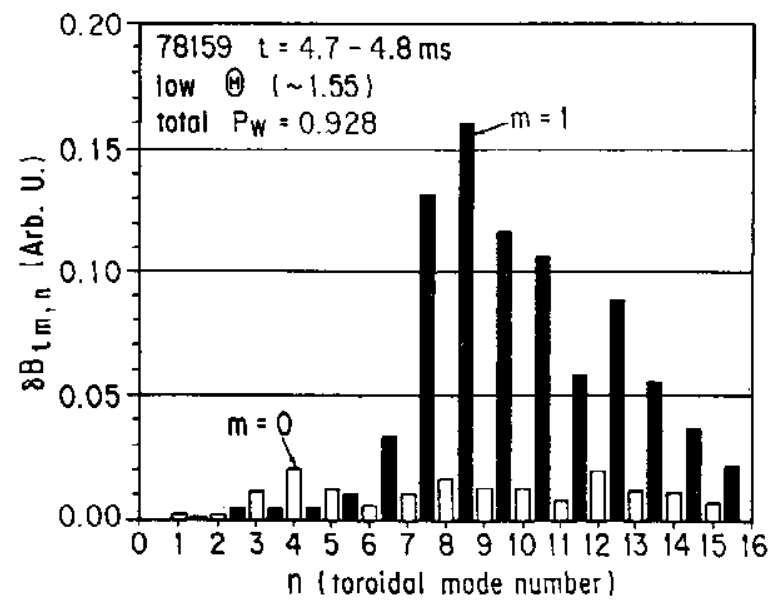

Fig. 4 Toroidal mode $(n)$ number spectra of $m=1$ and $m=$ 0 modes of the fluctuation of toroidal magnetic filed in the typical RFP discharge with low pinch parameter $(\sim 1.55)$ in TPE-1RM20 [17].

できるような状態，いわゆる stochastic な磁力線構造が 発生する，したがって，磁力線に平行方向の䊉子やエネ ルギーの伝播が半徍方向の輸送を生じさせる,

Rechester-Rosenbluth 型の異常搪散がプラズマの損失 を支配するようになるい18」。

この場合，熟拡散係数は以トの式で表される.

$$
\chi \sim(\delta B / B)^{2} v_{\text {the }} L_{\mathrm{c}}
$$

$こ こ て ゙ ， v_{\text {the }}$ は電子の熱速度， $L_{\mathrm{c}}$ は摇動のコネクシ ヨン長である.

An 等は, プラスマの抵抗による磁場の堿衰を補って RFPプラスマを定常的に維持するために必要なタイナ モモードの大きさを乱流理論から見積もり，この磁場摇 動による損失とジュール加熱が釣り合うことを仮定し て，以下の RFPのエネルギー閉し这め時間の比例則を 革いた [19]。

$$
\tau_{\text {E-tearing } m=1} \sim 5.8 f^{-1} v_{\text {the }}{ }^{-1} \beta_{p}^{2.5} a S^{2 / 3}
$$

一方，宮本は，タイナモ効果で主要な䡃きをするのは $m=0$ モードであると考えて, 以下の比例則を求めた $[20]$.

$$
\tau_{\text {E-tearing } m=0} \sim 0.45 Z_{\text {eff }}^{0.8} T_{\mathrm{e}}^{0.7} R^{2} n_{\mathrm{e}}^{-0.4} I_{\mathrm{p}}^{0.8}\left(1+T_{\mathrm{i}} / T_{\mathrm{e}}\right)^{-0.5}
$$

ここで，fは温度や密度の分布に依存する筀数（０.01 -0.1)，Sは磁気レイノルズ数（あるいは Lundquist 数） と呼ばれる量で, $S=\tau_{\mathrm{R}} / \tau_{\mathrm{A}}$, すなわち, 磁場の搪散時 間 $\tau_{\mathrm{K}}=\mu_{0} a^{2} / \eta$ とアルヴェン時間 $\tau_{\mathrm{A}}=a / v_{\mathrm{A}}\left(v_{\mathrm{A}}=B_{0}\right.$ $\left(\rho \mu_{0}\right)^{1 / 2}$ はアルヴェン速度) の比, $T_{\mathrm{e}}$ は電子温度, $T_{\mathrm{i}}$
はイオン温度, $R$ は大半径である.

これらの比例則は先のベータ值一定則より悲観的なも のであるが, 現在のプラズマパラメータの変化範用では, これら上記 $3 つ の$ 比例則のなかで，どれが実験を正しく 記逨しているかはまだはっきりとしていない[3,12].し かしながら，核融合护の条件へ外扱した場合には両者の 違いは大きく，タイナモ効果による磁場摇動を考虑した 比例則では現実的な炉設計はほとんど不可能であると子 想されている $[21]$.

\section{2 トカマク比例則との比較}

RFP ゙トカマクの閉じ込め比例則との比較を行う場 合, トカマクのどの比例則と比較するかが閣題になる。 RFP の加熟がジュール加熱だけであることを考えると Neo-ALCATOR 則との比較をすべきであるかもしれな いが, Neo-ALCATOR 則に含まれる安全係数への依存 性をRFPでどう取り扱ってよいかわからないので，こ こではITER-89P の L-Mode 比例則との比較を試みる. 非円形度を 1 とすると上記比例則は [22]

$$
\tau_{\text {E.ITER89P }}=0.048 M^{0.5} I_{\mathrm{p}}^{0.85} R^{1.2} a^{0.3} n_{1}^{0.1} B^{0.2} P^{-0.5}
$$

である.ここで，Mはイオンの質量数， $I_{\mathrm{p}}$ はブラズマ 電流 (MA), $R$ は大半径 $(\mathrm{m}), a$ は小半怿 $(\mathrm{m}), \quad \mathrm{n}_{1}$ は linc averaged electron density $\left(10^{20} / \mathrm{m}^{3}\right), B$ はトロイタル磁 場 (T), $P$ は加熱入力 (MW), である. RFP の場合 $P=$ $I_{\mathrm{p}} V_{1}$ (V消はnon-inductive part of toroidal loop voltage) である.またBとして何をとるかが問題となるが，ここ では定義そのままに外部卜ロイダル磁場 $B_{\mathrm{tw}}$ を用いた場 合と、RFPの主閉じ込め磁場がポロイダル磁場であるこ とを考虑して、ブラズマ表面のボロイダル磁場 $B_{\mathrm{p}}=$ $0.2 I_{\mathrm{p}} / a$ を用いた場合を考えることとする. 前者の場合は

$$
\tau_{\text {E-ITLR89P-Btw }}=0.048 M^{0.5} I_{\mathrm{p}}{ }^{0.35} K^{1.2} a^{0.3} n_{1}^{0.1} B_{\mathrm{tw}}{ }^{0.2} V_{1}^{-0.5}
$$

後者の場合は

$$
\tau_{\text {E-ITER89P-BD }}=0.035 M^{0.5} I_{\mathrm{p}}^{0.55} R^{1.2} a^{0.1} n_{l}^{0.1} V_{l}^{-0.5}
$$

となる，電子技術総合研究所の小型 RFP 装置 TPE $1 \mathrm{RM} 20$ の，䦥じ込か向上モードでない通常の放電条件 $\left(R=0.75 \mathrm{~m}, a=0.192 \mathrm{~m}, I_{\mathrm{p}}=0.16 \mathrm{MA}, n_{1}=0.14, V=15 \mathrm{~V}\right.$, $\left.M=2 . \tau_{\mathrm{E}}=0.4 \mathrm{~ms}\right)[23]$ で比較を行うと， $\tau_{\mathrm{E}-\mathrm{ITER} 89 \mathrm{P}-\mathrm{Btw}}=$ $1.3 \mathrm{~ms}$ ， 吕ITER89P-Bp= $2.3 \mathrm{~ms}$ となる。また，米国ウイス コンシン大学の MST 装置の通常の運転モード $(R=1.5$ $\mathrm{m}, a=0.5 \mathrm{~m}, I_{\mathrm{p}}=0.34 \mathrm{MA}, n_{\mathrm{l}}=0.1, P=4.4 \mathrm{MW}, M=$ $1, \tau_{\mathrm{E}}=1 \mathrm{~ms}$ ) [24] と比䡈すると, $\tau_{\mathrm{E}-\mathrm{ITER} 89 \mathrm{P}-\mathrm{Btw}}=3.4 \mathrm{~ms}$, $\tau_{\mathrm{E}-1 T E R 89 P-B p}=6.5 \mathrm{~ms}$ となる．どちらの䭪合も，実験で 
得られている閉じ込め時間はて下-TTFR89P-Btw の1/3, 㐂ITER89P-Bp の1/6程度である。さらに，第 3 章で述べる閉 じ込め改善モードで比較すると，TPE-1RM20の IHT モード $\left(I_{\mathrm{p}}=0.13 \mathrm{MA}, n_{\mathrm{l}}=0.15, V_{1}=15 \mathrm{~V}, \quad M=2\right.$, E $_{\mathrm{E}}$ $=0.6 \mathrm{~ms})[6.7 .23]$ の場合には，実験值は㧍扰よをて ITER89P-Btw $の 1 / 2 ， \tau_{\text {E.TTER89P-Bp }}$ の1/3である。また, MST $の$ PPCD $\left(I_{\mathrm{p}}=0.34 \mathrm{MA}, n_{\mathrm{l}}=0.1, P=1.4 \mathrm{MW}, M\right.$ $\left.=1, \tau_{\mathrm{E}}=5 \mathrm{~ms}\right)[24]$ の場合には，おおよそ $\tau_{\mathrm{E}-\mathrm{ITER} 89 \mathrm{P} .}$ Btw $の 70 \% ， \tau_{\text {E-ITER89P-Bp }}$ \% 40\%となる。通常，RFPは 閉じ迟めが非常に覀いと言われているはどには，その差 がないことがわかる、いず机にせよ，トカマクのLモー ド比例則が RFPにおいてそれなりの值を与えることは， 両者の想定されているエネルギー鍮送のメカニズムの違 い(トカマクでは静電的なプラズマの摇動が, RFPで は磁場の摇動が主要な役割を演じていると一想される) を考えると, 大変に舆味深い。

\section{3 新しい経跧的比例則}

最近，宮本によりRFPのエネルギー閉じ込め時間に 関する新しい経験的な比例則加提案された[25].これは, トカマクやヘリカル系で見られる，加熱入力の堌加に伴 う閉じ込めの琶化を考慮に入れたもので，上に述べた卜 カマクの比例剘を，RFに適合するように修正を加え た形となっている。宮本は以トに示すように,プラズマ 䉓流に対する依存性を若干変えて，2種類の比例則を提 案した．2番月の比例則には $I / N(I$ はプラスマ電流值, $N$ は電子の線密度， $\pi a^{2} n_{\mathrm{e}}$ ）の值による修正を加えている， 第一番目の比例則は

$$
\tau_{\text {E-MIY AMOTO-1 }}=0.024(R / a) a^{2} I_{\mathrm{p}} / P^{0.5}
$$

であり，2 番目の比例則は

$$
\begin{aligned}
& \tau_{\text {E-MIY AMOтO-2 }}=0.04 s_{0}(R / a) a^{2} I_{\mathfrak{p}} 1.25 / P^{0.5} \\
& s_{0}=1 \text { for } I / N>3.5 \times 10^{-14} \mathrm{Am}, \\
& s_{0}=(I / N) /\left(3.5 \times 10^{-14}\right) \text { for } I / N<3.5 \times 10^{14} \mathrm{Am}
\end{aligned}
$$

である、ここで， $P$ は加熱入力である．文献[25]で示さ れているように，この 2 つ比例則と先のベータ值一定 則を，実験デー夕に合わせて比較してみると，ここで示 した比例則の方がよく合っていることがわかる。また， この 2 つを此較すると 2 番目の方が若干よく合っている ようにも見えるが，実験デー夕の数が十分でないのでど ちらがよく合っているかは不明である。

宮本は, コらにDT反応のアルファ粒了加熱とオー ム加熟の和が，上に示した比例則でちえられるエネル
ギー損失と验り合う条件，いわゆる自己然烧条件の評価 を行い，第一番目の比例則の場命には，比例則で与えら れるものより $2-3$ 倍の閉じ込めの改善がないと現害的 な条件では自己然娔は実現不可能であるが，2番目の比 例則の場合にはブラズマ電流に対する依存性が強いの で，現状のままで現奏的な自己燃焼条件に到達できるこ とを示している。ただし、ここで宫本は先験値との比挍 を行う際，次の章で述べる RFPの閉じ达め向トモード (IHT モード $[6,7,23] ， \operatorname{PPCD}[24])$ の值を用いている ことを指摘しておく必要がある。すなわち，宮本の比例 則は，閉じ込め向上モードであれば，RFPで自己燃焼 条件の達成の可能性があることを示咬しているものとも 考えられる。

\subsection{RFPにおけるプラズマ輸送のメカニズム（震近の 実倹蛣果)}

最近，大型 RFP 実験装置（先に述べたMST [26]， および，イタリア電離ガス研究所の RFX [27]と最近実 験が始まった電子技術総合研究所の TPE-RX [28]）に よる研究が進展し，分布計測や様々な摇動計測により， RFP のプラズマ損尖のメカニズムが明らかになってき た. 大刑 RFP での特徽は,プラズマのコア部分では磁 場摇動による Rechester-Rosenbluth 型のプラズマ軨送 が支配的であることが明らかに示されることである，小 型喆置とは違って，人型装置では精度の高い温度・密度 の空到分布ひ测定が可能であること，また，加熱入力密

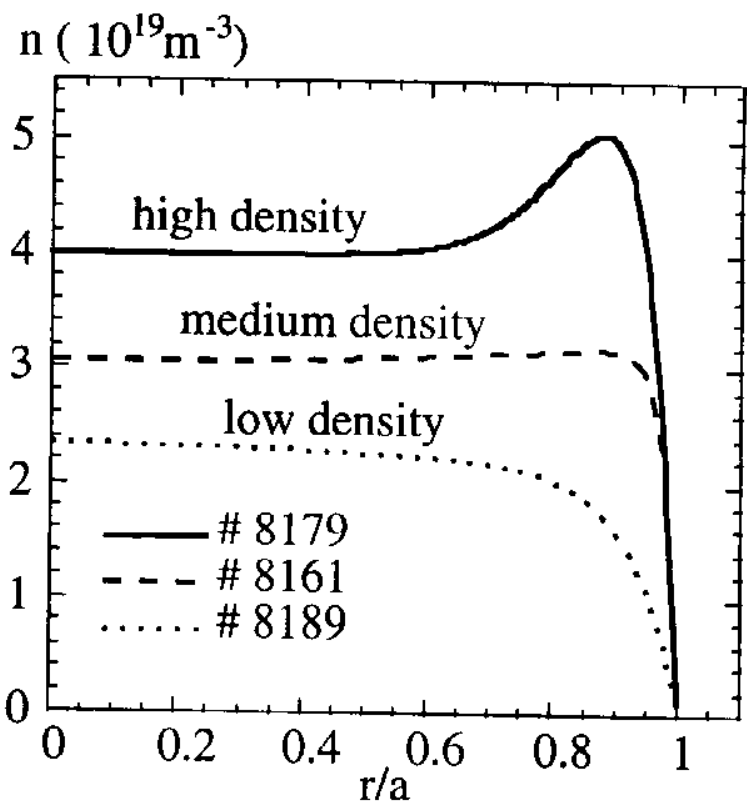

Fig.5 Density profiles in low $1 / N$ (high density, solid curve), medium $/ / N$ (dashed curve) and high $/ / N$ (low density, dotted curve) in RFX [30]. 
度が小さくなったこと（1 $\mathrm{MW} / \mathrm{m}^{3}$ 以下）も堁害して， stochastic な磁力線の効果によるプラズマ輸送が，より 鲜明に観測されるようになったものと考えられる。

RFX では Fig. 5 に示すように密度分布はプラズマの コアではほとんどフラットであり，周辺部分の閉じ込め の良いところで大きな密度勾配を文える構造となってい る [29-31]．特にRFX は第一壁をグラファイトタイル で覆っているためりサイクリング率が高く，高密度の運 轱領域 ( $I / N$ の小さな領域) では, 密度分布は中心部 が小さく周辺部分で大きい, hollow な分布となってい る.このような特殊な分布は, stochastic な磁力線のも とでの大きな径方向拡散速度と，壁からの大きな粒子流 入を考えることにより説明できるとしている[30].

$\mathrm{RFX}$ では $\mathrm{D} \alpha$ の絶対强度分布と密度分布の計湘から， 粒子の搪散係数を求めている[31]. その結果を Fig.6に 示す. ブラスマのコアでは $10 \mathrm{~m}^{2} / \mathrm{s}$ 程度で, $r / a \sim 0.6$ までは一定であり，それより外側では次第に減少して， 壁付近では一析小さい $1 \mathrm{~m}^{2} / \mathrm{s}$ 程度となっている. 一方， TPE-1RM20においては, 同様の計測から粒子拡散係数 を評価して, 中心で $2 \mathrm{~m}^{2} / \mathrm{s}$ 程度で, 周辺に向かって增 加し， $r / a \sim 0.8 て ゙ 8 \mathrm{~m}^{2} / \mathrm{s}$ となる, RFX とは逆の㹡散保 数分布の変化を得ている[32].この搪散保数から評価し た䊉子閉じ込め時間（０.75 ms）は，ボロンのレーザー ブロー人射実験で得られた值（０.8 ms）と非常に良い 一致を示しているので，計測上の問題からこのような伯 が得られたのではないと考えられる.中心部分で平坦で, 周辺部分に大きな勾配を持つ密度分布は，MSTに扔い ても観測されているが[33], RFXやMST と TPEの装 置のスケールの差(あるいは加熱入力密度の差の可能性 もあるがにによって，なぜこのうな違いが出てくるか 興味のあるところではある.リミ夕材料の違い（RFX は全グラファイト壁, MST はダラファイトリミタ, TPE-1RM20はモリブデンリミタでカーボンフリー) が 影良している可能性も考えられるが，理由は今のところ よくわかっていない.

MST [34,35], RFX [36], TPE-IRM20 [37] ), 周 辺プラズマのトリプルプープ测定の実験から,プラズ

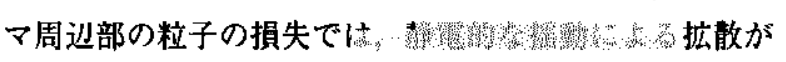
中心的な役割果たしていることが明らかとなってい る.すなわち, RFPの粒子損失においては，コアでは 磁場摇動に上る搪散が, 周辺では静電的な摇動に上る拡 散が、上要なメカニズムである.

また，RFXでは電子温度分布と密度分布の測定結果 と, 適当な仮定を用いて評価した電子へのオーム加熱入
ノ分布により，実効的な電子の熱拡散保数の評価を行っ ている (Fig. 6 参照) [29,31]. 熱㹡散係数の中心付近 の大きさは $400 \pm 200 \mathrm{~m}^{2} / \mathrm{s}$ 程度で，面白いことに粒子搪 散係数のイオンと電子の質量比の $1 / 2$ 乗（約 $40 ）$ 倍の大 きさになっている，これは，㹡散の基本メカニズムが、 stochasticな磁力線に沿った粒子の熱運動であることを 示す一つの証樾である.すなわち，粒子拡散は両極性電 場のためにイオンの運動に支配されるのに対して，熟拡 散は両極性電場が効かないので, 電子の運動に支配され ていることを反映しているものと解粕される.

一办，MSTのグルーブは，全体の損失を考えると熱 㹡散係数はRechester- Rosenbluth型ではあるが, 損失 は電子の熱速度ではなくイオンの熟速度で決まる，すな わち，熱損失に関しても雨極性的な振る舞いが見られる と主張している[38].この両者の違いの原因は周辺部の 実効的な㹡散保数の減少をどのように解釈するかの差， すなわち，磁力線はプラズマ表面まで全面的にstochasticで輸送の減少は両極性的な振る舞いによるとするか， ブラズマ周辽部分では何らかの原因で磁力線はstochasticでなくなり軨送が減少するとするかの違いであると 考えられるが，正否を含めた詳しい解析は今後の課題で ある。

REPUTEの静電プローブによる計測では[39]，プラ ズマ周辺部分の熱流速への静電的な摇動からの寄与は小 さいことが示されている. 一方, MSTで行われた熟流 プローブの計測では [40], コア部分においては，磁場摇 動でstochasticになった磁力線に沿う熱の流れによる径 方向の熟流束が主要な熟損失の原因であるが，周辺部分

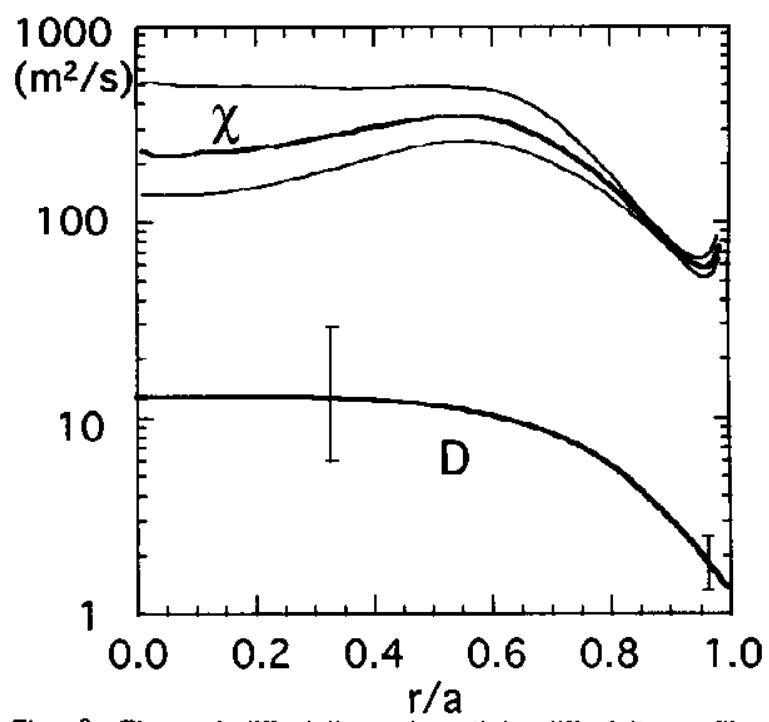

Fig. 6 Thermal diffusivlty and particie diffusivity profiles with $t_{p}=800 \mathrm{KA}$ in RFX [31]. 


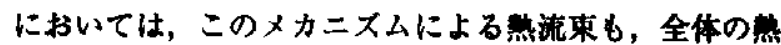
の流れと比べて無視できる程小さいことが示されてい る.また REPUTE と同様に，静電的な摇䡃による熟流 束への寄与は，イオンによる奇与が電子と同程度あると 仮定してもせいぜい $30 \%$ 程度以下であり，さらに，周 辺部分の放射損失は㧤扰よそ $10 \%$ - $20 \%$ 程度である 測定されている。したがって，RFPでは，現在のとこ ろ少なく見皘もっても，周辺部分では全熟損失の $50 \%$ 程度の熱損失のメカニズムが不明である.メカニズムと して考えられる候補としては，イオンの異常損失, 高工 ネルギー電子流と静電摇動の相互作用による買常損失, トーラスのトロイタル方向の特定の場所に localize した 磁場摇動 (wall locked mode)による非対称的なエネル ギー損失，等が考えられるが，その解明は今後の課題で ある.

これら最近の RFP の輸送現象に関する結果をまとめ ると, 加熟入力密度の小さい大型装置では, 磁場嗳動に よって stochastic になった磁力線に沿う粒子，および エネルギーの流れによる損失, いわゆる RechesterRosenbluth 型の翼常拡散がプラズマのコア部分で支配 的であるということができる.したがって，エネルギー 閉じ込めの比例則としては，装置が大型化するに従い， ベータ值一定則よりは，ティアリンク則に近いものにな っていくのではないかと予想される。

\section{5 糧搯勒の比例則}

このように，大型 RFP 䒾䀧の実験結果から，RFPの 輸送, 特にコア部分の輸送では, 磁場摇動による Rechester-Rosenbluth 型の拡散が主要な役割を演じて いることが明らかとなってきた、この磁場摇動の原因は タイナモ効果に起团するものであり，RFPの磁場配位 の維持と本質的にかかわっている．したがって，ダイナ モ効果に必要な磁場摇動の大きさが，プラズマパラメー 夕の向上とともにどのように減少するか，すなわち，磁 場摇動レベルの比例則を求めて，核融合炬に必要なプラ ズマパラメー夕領域で, 磁場摇動が十分小さくなり, 拡 散係数が娍少して，十分な閉じ込めが実現できるかどう か確かめることが, 重要な問題になる。

ただし，ここで次のことを指摘しておく必要がある.

もし仮に，核融合炬として定常灯しかあり得ないとする ならば，RFPにおいてもいずれにせよブラズマ電流を 直接的に駆動することが必要になり，その場合には， RFPではトロイダル電流だけでなくポロイダル電流も 直接駆動されるので，ダイナモ効果は不要となる。した がって,ダイナモ効果に必要な磁場摇動はなくなり，そ
の摇湲に基つく摭散は考虑する必要がないことになる。 この場合には, ベー夕値限界や静電摇動，あるいはタイ ナモ効果と関倸のない磁場摇動等による損失が，满足の いくレベルにまで低減できるかどうかが重要な問題とな る.さらにそれに加えて，効率的で，しかも分布制御が できる直接電流駆動が可能かどうかが，RFP 炣の塞現 可能性を決める大きな課題となると考えられる．RFP の直接電流駆動の試みについては次の3章で紹介する。

この観点からすると, 磁場摇動の此例則等は重要では なく、RFPにおける電流駆動，あるいは配位の定常的 な維持力法について研究を進めるべきであるという議論 になるかもしれない.しかしながら，RFP炬としては， ロングパルスの準定常㸝，あるいは磁場配位の自然減衰 の期間を利用してダイナモ効果（磁場摇動）を抑え，诚 衰時間内でプラズマ閉じ迟めと核燃焼を行う非定常的な バルス炬，という方法も考え得るので，必ずしも磁場摇 動の比例則が意味がないわけではないままたダイナモ 効果の物理的なメカニズムの理解という点でも, 磁場搯 動の比例則は興味が持たれるところである.

2.10 式 (3) また, 電場は $v_{A} B_{0}$ で, 電流密度は $\boldsymbol{B}_{0} / \mu_{0} a て ゙$ 正规化し て無次元化すると，

$$
E_{0 \|}+\langle\boldsymbol{v} \times \delta \boldsymbol{b}\rangle_{\|}=S^{-1} J_{0 \|}
$$

となる.ここで $S$ は先に与えた磁気レイノルズ数で ある.

最も簡単な磁場摇動の比例則は，上の式でトロイダル 磁場け逆転面を考えると，そこでは $E_{01}$ がぜロとなるの で, $\boldsymbol{v}$ と $\delta \boldsymbol{b} の S$ 依存性が同じで, フェーズ差も変化し ないと仪定すると， $\delta b \propto S^{-1 / 2}$ と求めることができる. この比例則は Connor-Taylor $\sigma$ 抵抗性 MHD モードに 対する次元解析から得られた結果とも一致している [10].また, An 等の乱流理論の計算では $\delta b \propto S^{-1 / 3} か ゙$ 得られている[19]. 一方, 最近の Mattorによる計算で は[41], タイナモ効果が問欠的に起こる discretc dynamoでは, $\delta b \propto S^{0}$ か，連続的に起こる continuous dynamoでは, $\delta b \propto S^{-1 / 1}$ が導かれている. ただし, discrete dynamoでは磁力線が stochastic になるところの磁場摇 動だけを取り出せば $\delta b \propto S^{-1 / 2}$ が得られる。

実験的には，La Hayc等によるOHTEでの㹁測で [42]， $\delta b \propto S^{-0.51}$ が $S$ 小 小さい領域 $(100-4.000)$ で得られて いる.また，服部等による TPE-1RM15のSの大きな 領域 $\left(5 \times 10^{4}-10^{6}\right)$ での実験では, $Z_{\text {eff }}$ が变化しないと仮 定して, $\delta b \propto S^{-1 / 3}$ を得ている[15]. しかしながら, 最近, 
Stoneking等によりMST菨䈯で行われた実験では[43]， 完全にではないが $Z_{\mathrm{eff}}$ の変化を取り入れることにより， Fig. 7 に示すように電子密度の高い状態では， $\delta b \propto$ $S^{-0.18}$ の，また密度の低い状態では， $\delta b \propto S^{-0.07}$ 比例 則が得られるている，ただし，彼らの実験では，電子密 度の高い,あるいは低い状態は，I/Nの小さな（２× $\left.10^{-14} \mathrm{Am}\right)$ ，あるいは大きな $\left(\sim 6 \times 10^{-14} \mathrm{Am}\right)$ 状態と して記述されている。このことは，磁場摇動はSだけ で決まるのではなく，それ以外の電子密度に関係したパ ラメータにも依存していることを示している。また， $Z_{\text {eff }}$ を一定 $(=2)$ と仮定すると， $I / N$ 小さいところ では $S^{-0.28}$ と，TPEの結果に近いものが得られている.

さらに, MST では, プラズマの運動の分光学的計測 と磁場摇動の計測を同時に行うことにより，ダイナモ效 果を与える速度と磁場摇動のベクトル榠白体の大きさを 求めた[33]. その絬果，ベクトル積の比例則は，|〈v $\delta \boldsymbol{b}\rangle \mid \propto S^{-0.7}$ 程度となり，Sの增加により速やかに隇少 するが，速度自体の大きさは，磁場と同椂にそれはど速 く減少しないという結果を得ている $\left(v_{\phi} \propto S^{-0.19}, v_{\theta} \propto\right.$

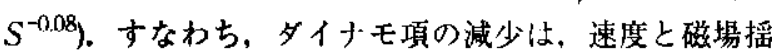

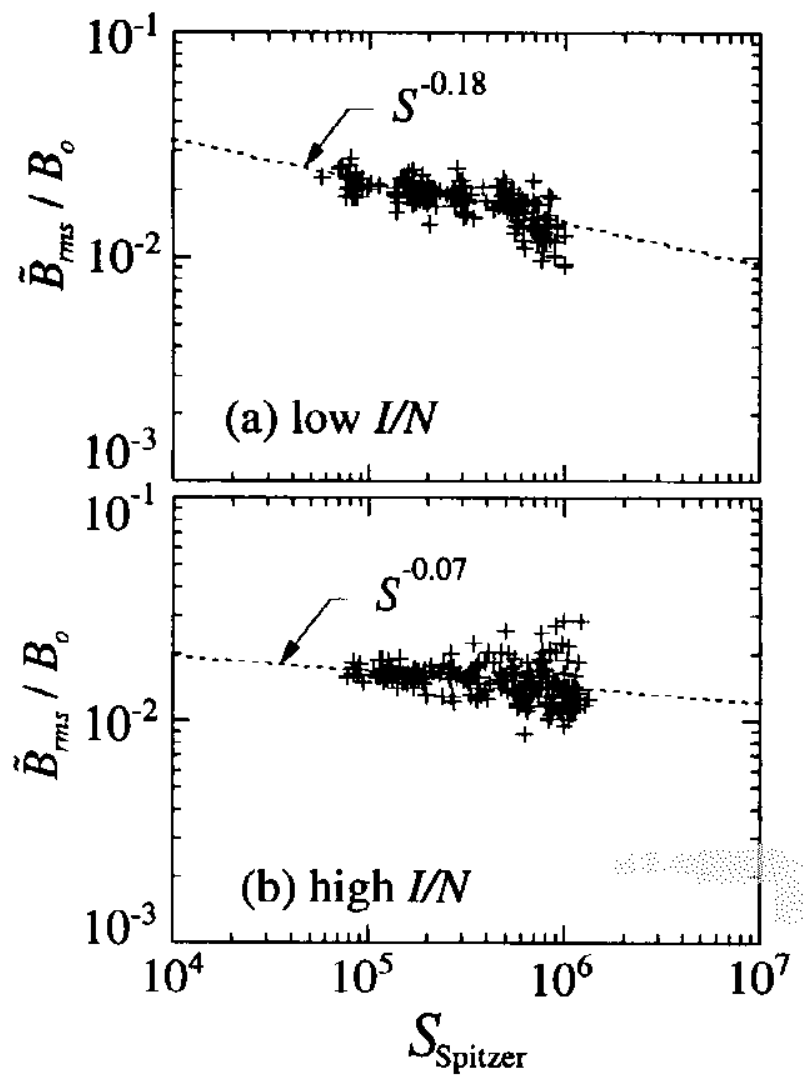

Fig. 7 The Lundquist number scaling of the rms magnetic fluctuations in MST [43].
轩の大きさそのものの堿少よりは，互いの間の cohcrence が減少することによりもたらされることが示され ている.

この MSTの結果は最近の実験で得られたものであ り， $Z_{\text {eff }}$ の值の変化を不十分であるとはいえ取り入れて いることから，現状では最も精度の高いものであると考 えられるが，この比例則が RFP一般に成り立つもので あるかどうかは，同様な比例則が他の装置でも見いださ れるかどうかによっており，RFX，あるいは TPE-RX 等の，ほかの大型装置による実験結果が待たれるところ である。

$\delta b \propto S^{-\alpha}$ なる比例則を考え, Rechester-Rosenbluth 梨 の拡散を考えると、フラズマ閣じ込めは $\alpha$ の值により 大きな影锌を受ける. 例之ば， $S^{-1 / 2}$ であるか， $S^{-1 / 4}$ と なるかは大きな違いで, $\delta b \propto S^{-1 / 2}$ の時には $\chi \sim T_{\mathrm{e}}^{-1}$ と なり電子温度の上昇とともに大きな改善が期待できる が, $\delta b \propto S^{-1 / 4}$ の時では $\chi \sim T_{\mathrm{e}}^{-1 / 4}$ となり改善は小さい. さらに，先に示したMSTの比例則では, プラズマパラ メータの向上に伴う閉し込めの改善はほとんど期待でき ないことになる。もし，MSTの結果が普逼性を持つも のであるならば，仮に $\delta b \propto S^{0.18}$ の比例則を用いること ができるとしも，これまでの $\delta b \propto S^{-0.5}$ の比例則に基 づく楽観的な期待に反して，炬への展望は蕨しいものと ならざる得ない。ちなみに，RFP 核尉合炻の設計例と して知られているTIT $\Lambda \mathrm{N}$ が[44]実現できるためには， 最低でも $\alpha=0.4$ 程度が必要であると考えられている。

\section{RFPにおけるプラズマ閒じ込め向上の試み}

これまで述べてきたように，大型 RFP 装㯰の実験で はこれまで小型装㯰の実験から予想されていたベータ 値一定則ではなく，磁場搯動による Rechester-Rosenbluth 型の拡散が支配的であり，しかも最近の MSTの 実験では，磁場摇動自体も磁気レイノルズ数の增加，す なわち、ブラスマパラメータの向上にしたがって，期待 されたようには減少していかないことが示されている.

しかしながら，最近になって，RFPのナ゙ラズマ閉じ 込めを改善するいくつかの方法が提案され，その効果を 実証する実験的な成果が得られつつある.ここでは， RFPにおけるプラズマ閉じ込めの改䖭の試みについて， 主なものをいくつか紹介する．

まず最初に，直接電流駆動を用いてポロイダル電流を 駆钦して、タイナモモードを安定化する方法を紹介する。 これは，先に述べた完全ダイナモフリ一な，RFPの定 常军転につながるもので, 本命ともいうべきものである. 
プラズマ周辺のポロイタル電流の直接駆動の先駆的な 試みは, MST でプラズマアークの電流源を用いた直接 電流注入実験により試みられたが $[33 ， 45]$ ，様々な実験 上の制限から明確な閉じ这め改善を示すには至っていな い.ここではこの実験の紹介は次の機会に讓ることとし て、これとは別に行われた洁辺部分の電流駆動の効果を 示す数侑計算の絬果を示すことにする，また，簡易的な 方法で周辺部のプラズマ電流の直接駆動の效果を検証す るために行われた, インタクティブなポロイタル電流駆 動の実験, 特に, その結果得られた大幅な閉じ込め性能 の向上について述べる。

また,プラズマ電流と平均トロイタル磁束の堿率率を 適切に制卸することにより，高ピンチパラメータ領域で のポロイダルベータ值の増加と，閉じ込めの改善が可能 であることを亦す笑験を紹介する。さらに、トカマクの Hモードとの類似性が予想される，プラズマ周辺部分の シアフローによる閉じ込め向上について簡単に触れる。

最後にダイナモ效果を起こすには，一般的には多数の モードの非線形的な相顶作用が必要であり，それらの モードの磁気島の重なりによって生ずる stochastic な磁 力線が，第じ込めを覀化させる原因となっていると考え られるが, 条件によってはダイナモモードのエネルギー がーつのモードに集中し，いわゆる single helical state が実現されることがある。この場合には磁気島の重なり がなくなり，閉じ込めが向上することが予想される。こ れを示惨する実呀絬果と理論的な檢討を紹介する [46].

\section{1 流流のシミュレーション}

結局のところRFPの酒位維持にダイナモ効果が必要 となるのは，RFPの MHD 的に安定な電流分布を支え るために必要な電場分布を，外部の磁束变化で与元るこ とができないためである，したがって，直接的な電流駆 動で電流分布を維持することができれば，必要なタイナ モ効果の大きさ，すなわち必要な磁場摇動のレベルを低 娍のるいはなくすことが可能になることが想定される.

この予測に基づき，服部等は，ポロイタル電流の一部 を，NBI，あるいは低域混成波で駆動した場合の，磁場 摇動の㧕制による閉じ込め特性の向上と, 全体のエネル ギーバランスに与える効果，ならびに核能合炉の経済性 へのインパクトを評価して，電流俚動のパワーを考府に 入れても，全体としてのエネルギー閉じ込め時間の向上 が可能でありこの方法が有望であることを示した [21，47，48].また，椎名等により速波を用いた電流駆動 の計算が行われており，入射方法（アンテナ）の問傿を うまく解決できれば, 高い駆動効率を持った電流聑動が (a)

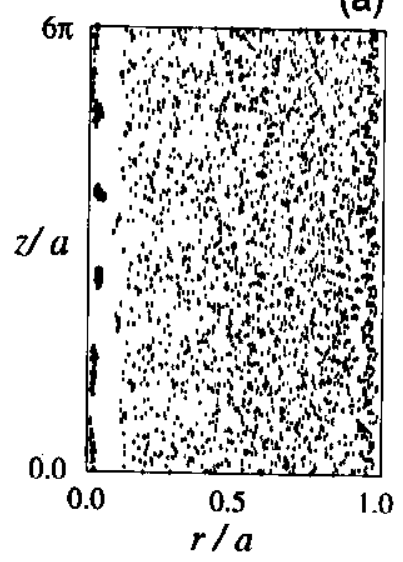

(b)

Fig. 8 Simulation result of magnetic-field line puncture plots in the axial-radial plane (a) without current drive and (b) with the additional ado-hoc current drive (the electron force) [50].

可能であることが示されている [49].

Uchimoto 等は [50], 三次元 MHD の円筒座摽系に求 ける数值シミュレーションで, 版辺部分のポロイタル電 流を強制的に腎動する，仮想的な項を付加した計算を行 った。その結果を Fig. 8 にボす. 図は $r-z$ 面での磁力 線のポアンカレプロットを示すが，駆動項がない場合に は磁力線は stochastic であるが，俚動項をつけ加えるこ とにより中心付近の磁力線は stochastic でなくなり磁 気面が形成されることがわかる。さらに，Uchimoto 等 は, MST装圈において駆動方法として低域混成波を用 いた場合の伝投特性, 吸収, 䟓動効率等の計算を行い, 必要な周波数, 凬折率, パワー等を見積もって, $1 \mathrm{MW}$ 程度の駆動電力で磁場摇動の抑制が期待できる実験が可 能であることを示している：この結果に基づき，MST 装塔では低域混成波を用いた電流駆動が計画されてい る.ただし，当面は入射電力の制限から，全プラズマ電 流ではなく，周辺部分のポロイダル電流だけを駆動する 予定である。

\section{2 パルスポロイダルロ流睤 (PPCD)による閏じ込 め改器}

周迁部分のポロイダル電流の駆動によるダイナモモー ドの安定化を，高周波等による直接的な電流駆動の泮備 が整う前に，簡単な方法で検証するため，MST 漖圈で Pulse Poloidal Current Drive (略して PPCD) が試み られた[9，24，51].これは，逆磁場ピンチ配位を形成し て隼定常状態に達するあたりで, 外部トロイダル磁場コ イルの電流をパルス的に変化させて（逆転をパルス的に 


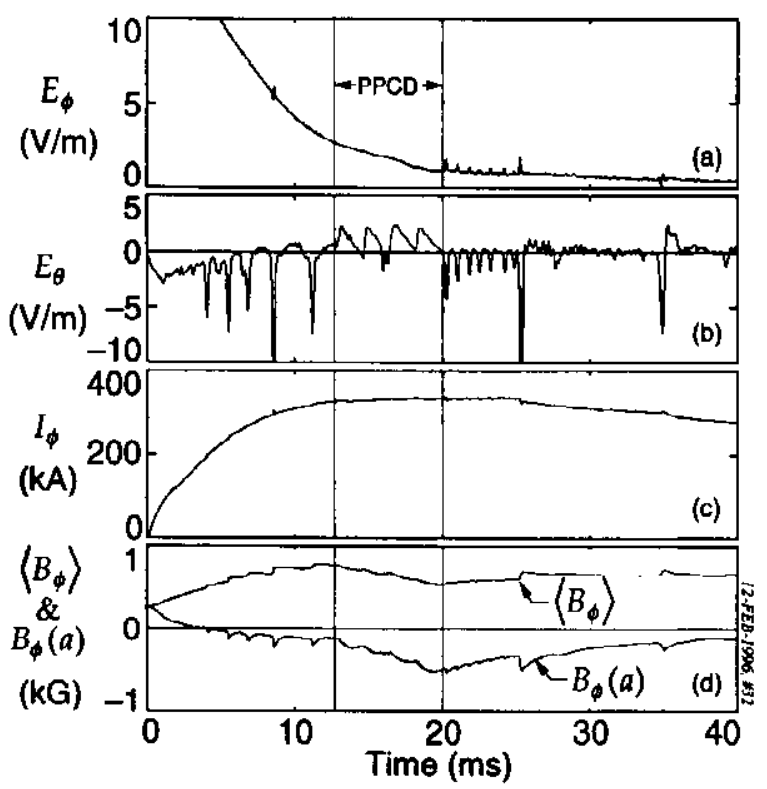

Fig. 9 PPCD discharge in MST, (a) surface toroidal electric field, (b) surface poloidal electric field, (c) toroidal plasma current and (d) averaged and surface toroidal magnetic field [9].

深くする)，プラズマ周辺部のポロイタル電流をパルス 的に駆動するものであり，トランジェントではあるが, 上に述ベたダイナモモードの交这化の検証が可能である。

Figs. 9,10にその結果を示す。外部卜ロイダル磁場を Fig. 9 のように変化することにより，大きな磁場摇動は なくなり，拡散係数が滅少するとともに，軟 X 線の信 号が增加していくことがわかる，平均的には磁場摇動の レベルはおおよそ半分に減少する。実験データの解析か らは，電流分仍が変化して MHDの線形安定性が向上し たとは単純に解秎できないことが示されている．したが って，磁場摇動減少の原因として最も叮能性の高いと考 えられるメカニズムは，外部卜ロイダル磁場の変化によ って発生したポロイダル電場がポロイダル電流を一部哥 動するため，ポロイダル笔流を駆動するのに必要なダイ ナモ効果の大きさが低隇することであると考えられる。 ただし，これ以外の原因，例えばシアフローによる MHDモードの安定化（もっともこのためにはアルヴェ ン速度に近い回転が必要であるが, 現在の RFPで完全 に不可能であるとは言い切れない）等が考えられないわ けではなく，今後のより詳しい解析が必要である。いず れにせよ PPCD ではこの磁場摇動レベルの低下により Rechester-Rosenbluth 型の搪散が低隇して，閉じ达め が改养したと推定される。

Table 1 にプラズマパラメータの, PPCDとそうでな

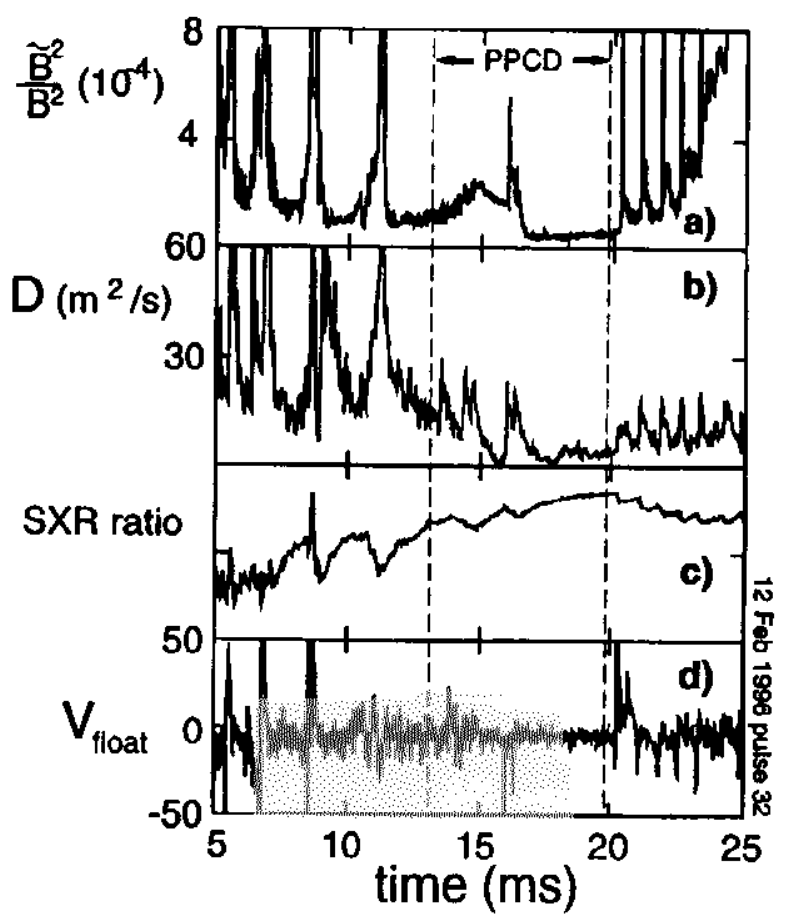

Fig. 10 PPCD discharge in MST, (a) rms magnetic fluctuations at the plasma surface, (b) estimated global particle diffusion coefficient, (c) ratio of beryllium filtered surface barrier diode signals indicating central electron temperature and (d) the floating potential signal from a Langmuir probe [42]

Table 1 Comparison between ordinary and PPCD discharges in MST.

\begin{tabular}{lll} 
& Ordinary & PPCD \\
\hline Plasma Current & $340 \mathrm{kA}$ & $340 \mathrm{kA}$ \\
Electron Density & $1.0 \times 10^{19} \mathrm{~m}^{-3}$ & $1.0 \times 10^{19} \mathrm{~m}^{-3}$ \\
Central Electron & $230 \mathrm{eV}$ & $390 \mathrm{eV}$ \\
$\begin{array}{l}\text { Temperature } \\
\text { Poloidal Beta }\end{array}$ & $6 \%$ & $9 \%$ \\
Input Power & $4.4 \mathrm{MW}$ & $1.3 \mathrm{MW}$ \\
$\begin{array}{l}\text { Magnetic Fluctua- } \\
\text { tion Level }\end{array}$ & $1.5 \%$ & $0.8 \%$ \\
Energy Confine- & $1 \mathrm{~ms}$ & \\
ment Time & & $5 \mathrm{~ms}$ \\
\hline
\end{tabular}

い時を比較したものを示す. PPCD 時にはプラスマへの

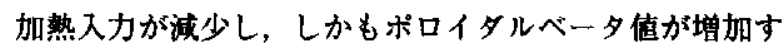
ることからおおよそ5倍のエネルギー閉じ込め時間の向 上が見られる。これは磁場摇動レベルの減少から予想さ れる值とほぼ致している。また，後で述べるように PPCD モードでは，プラズマ中のシアフローの発生によ る静電摇動の娍少も観湘されている，また，PPCDによ るエネルギー閉じ运め時間の向上は RFX 装䐬において も観測されている $[52]$. 


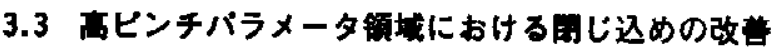
(Improved High Theta モード, IHT モード)

安定性の計算によると，2 章で導入したピンチパラ メータ $(\theta)$ が大きく, 逆転パラメータが梁いほど, 高べー タブラズマの保持が可能であることが示される[53]。こ れは，高ピンチパラメー夕領域では，磁力線の shear が 大きくなることから容易に予想されることである。しか しながら, 実際の実験の高ピンチパラメー夕領域では, 大きなエネルギー損失を伴う澈しい不安定性が間久的に 現れ（トカマクの鋸波に類似した変動が軟 X 線の信号 に現れる)，ポロイダルベータ值の上昇は見られていた ものの，良好な閉じ込めは実現できていなかった[54].

しかし，TPE-1RM20の実験では，ブラズマ電流と逆 転卜ロイタル磁場の波形を適切に制衙することにより， 大きな軟 X 線の崩䘫が現れない高ピンチバラメー夕領 域の RFP プラズマを，10 ms 程度の間安定に保持する ことに成功し，この運転モードを Improved High Theta Mode (IHTモード) と名们けた[6,7,55]. Fig. 11 [17]にIHT モードと，そうでないときの軟 X 線の時 間変化を比較したものを示す．IHTモードでは，ボロ イタルベータ值が增加 $(\sim 8 \% \rightarrow 20 \%)$ する一方，オー 厶加熱入力はほとんど変化しないので, エネルギー閉じ 达め時間は 2 倍以上增加（ $0.2 \mathrm{~ms} \rightarrow 0.5 \mathrm{~ms} ）$ する。 IHT モードではタイナモ効果に対応すると考えられる 磁場摇動のパワーは，通常の場合と比較して扰扰上そ三 分の一に減少する[6]．閉じ这め時間の改善はこの摇動 の隇少から予想される Rechester-Rosenbluth 型の搪散 の減少とお扰よそ一致している。

IHT モードを得るには，ブラズマ電流とプラズマ中 のトロイダル磁束（平均トロイダル磁場）を，適切な城 衰率で減衰させることが必要である。すなわちブラズマ が本来持つ減率率 $R / L \quad(R$; プラズマの実效抵抗, $L$ ；内部インタクタンス）に近い隇墪率を実現すると， IHT モードが得られる確率が最も高くなることがわか っている[55].プラズマの自然な抵抗隇衰に近い状態で は, トロイダル磁束の生成が必要ないのでダイナモ効果 も不用となり，磁場摇動の低滅による閉じ迟めの向上が 期待できる．またこの結果は，昔の ZETA 装圈で，磁 場摇動の小さい閉じ込めの良いフェーズ，いわ吼 Quiescent Period (QP) が, 電流の隇衰フェーズでの及 観測されたことを思い出させるものである[56]，

もっとも、プラズマの抵抗率の分布が空間的に一様と いう理想的な状態であれば，相対的な磁場分布を変えな いで,安定性を保ったままの・样な隇衰が可能であるが，
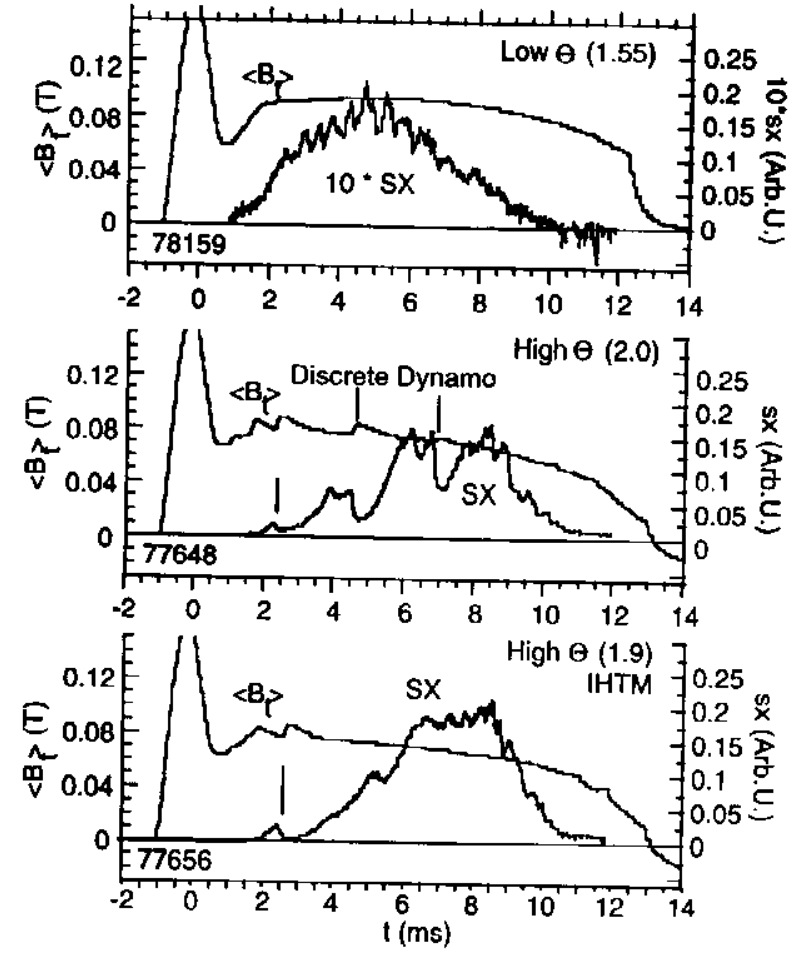

Fig. 11 Comparison of averaged toroidal filed, $\left\langle B_{\rangle}\right\rangle$and soft $\mathrm{x}$-ray emission, $\mathrm{SX}$ in low theta discharge (top) high theta discharge with discrete dynamo (middle) and high theta discharge with improved confinement, IHT mode (bottom) in TPE-1RM20 [17].

現実のプラズマでは，周辺部分の温度か低く抵抗率が高 いため，電流分布の中心们の集中による磁場分布の相対 的な変化が起こり，いずれは不安定な分布一と移行して しまう。しかしながら，壁からの川性粒子や不純物の放 出学可能な限り押さえて, 䧓辺部分の電子温度を高く保 つことができれば，磁場分布の変化を遈くして，安定な 配位を比較的長時間保つことが可能となると考えられ る. TPE-1RM20 で，十分な放電洗浄の後にのみ IHT モードが得られたことは，このことを示唆している。 ま た, TPE-1RM20ではモリブデンのリミタを用いていた ので（完全にタラファイトフリー，中性精子の放出が 少なかったことも，何らかの役割を果たしていたと考え られる。

TPE-1RM20 の IHT モードは, 磁場の減衰フェーズ のみで得られるトランジェントなものではあったが，低 密度領域で，20\%の高いベー夕を持つRFPのプラズマ の維持と, それによる閉じ込めの改善が可能であること を示した点で, 重要な結果である.

IHT モードの磁場摇動の特徵は, 摇動が単一の $m=1$ のモードに集中し，しかもそのモードのトロイタル方向 
ヘの回転が, MHD 不安定性の安定化に重要な役割を果 たしていることである $[16,17,55]$. Fig. 12 にHT モー ドの場合の, $m=0$ と 1 のモードの $n$ スペクトルを示す. 先にFig. 4 で示した低 $\Theta$ の場合と比㜞すると，低 $\boldsymbol{\theta}$ の 場合には, $n=7,8,9,10 \cdots$ と, 次第に減少していく多数 の $m=1$ モードが问時に存在しているが, IHT モード では, $m=1 / n=7$ のードにほとんどの摇動エネルギー が集中していることがわかる．磁場摇動のエネルギーが 単一のモードに集中すれば, 複数のモードの磁気島の重 なりが解消し，磁力線が stochastic でなくなって，閃じ 込め性能が改善することが期待できる。またこのモー ドはトロイダオ向に回転しているが，回転の停止と大 きな磁場搯動の発生（軟 X 線の大きな崩壊）とは強く 関連していることがわかっている。

これらの観測結果は, IIIT モードのメカニズムが, 先に述べた，磁場隇就フェーズに㧍けるダイナモ効果の 低減だけでもたらされたものではなく，次に述べる，シ アフローによる摇動の安定化や, single helical 状態と も関連している叮能性を示しているものと考えられる.

\section{4 シアフローによる䦥じ込めの向上}

トカマクや゚リカル系では，プラズマのトロイダル， あるいはポロイダルの流れの小半径方向のシア, いわゆ
るシアフローの存在と, 閉じ込め性能が向上する様々な 連転モード（例えば， $\mathrm{H}$ モード等）との閒に，密接な 関係の見られることが知られているが，RFPに抢いて も閉じ这め改善モードでは，プラズマのエッジ部分で電 場の半径力向の変化による $\boldsymbol{E} \times \boldsymbol{B}$ ドリフト速度のシア が存在し（大きくなり），それが静電摇動の抑制による 粒子損失の抑制に貢献していることが, MSTの実験で 示されている $[57,58]$. MST では, プラズマバイアス 実験 [59], Enhanced Confinement (EC) モード, PPCD の3つの閉じ込め改善モードが得られている. PPCDに ついては先に紹介したが, プラズマバイアス害験は電極 をプラズマ周辺に㧴人して暼圧をかけ，泃辺部の電位を 制御しようとするもので, 最初から電場の制御によるシ アフローの発生をねらった実験である，一方，EC モー ドは，運転条件を適切に選ぶことにより自発的に現れる 閉じ込め向上のモードである. ECを得るためには，低 密度運転, トロイダル磁場の深い逆転（深いF）, 真空 容器壁のコンディショコング（boronization と強力な pulse discharge clcaning), および適切な水素ガスの供 給（ガスパフではなく壁からの供給ーリサイクリングの み）がキーポイントである.これはTPE-1RM20におい て IHT モードを得る際に必要な条件と同じである。
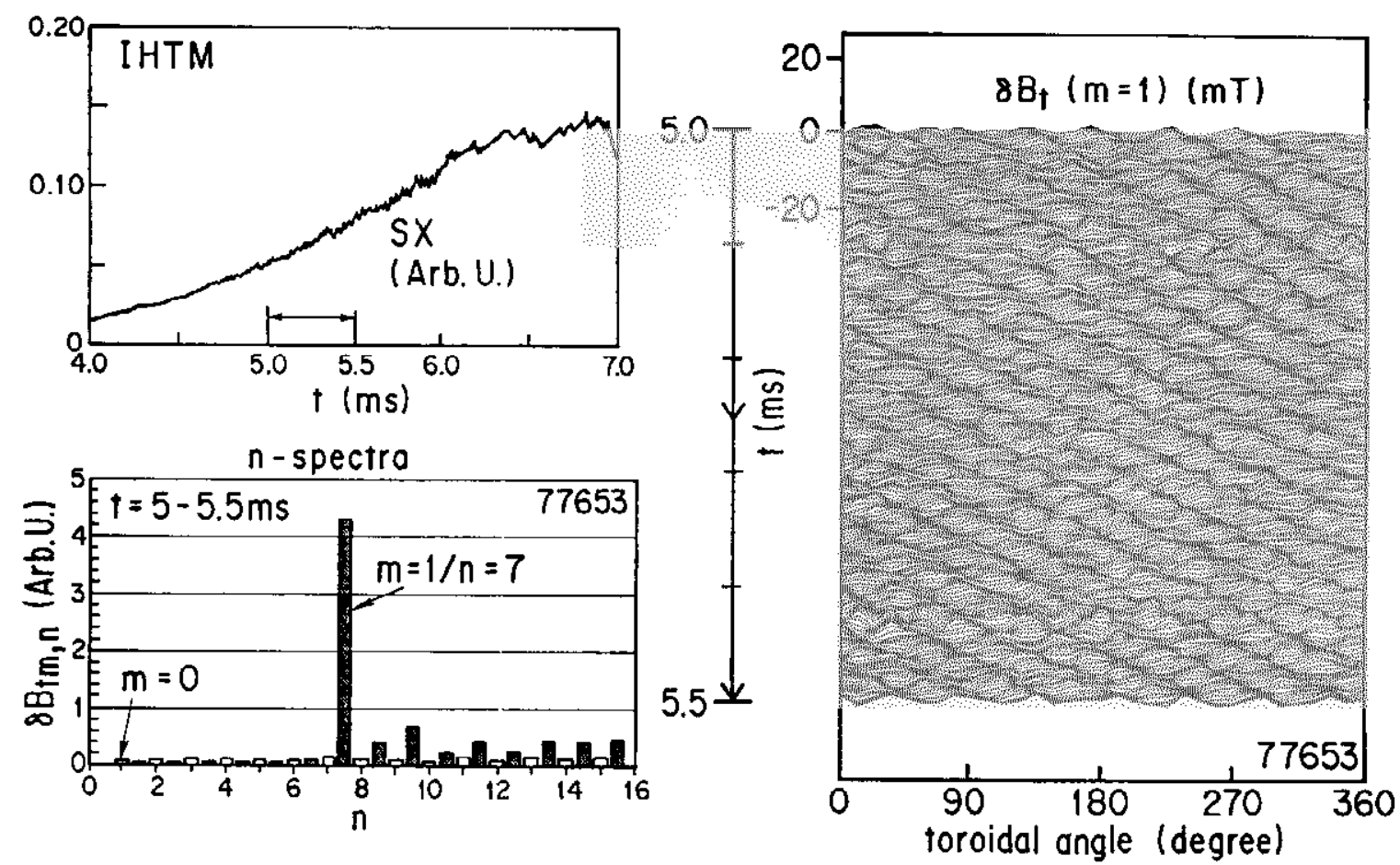

Fig. 12 Example of the IHT mode in TPE- 1 RM20, increase of SX, toroidal mode $(n)$ number spectra of $m=1$ and $m=0$ modes and time evolution of the toroidal variation of $m=1$ fluctuation of toroidal magnetic filed with high pinch parameter (-1.9) [55]. 
MSTでは上記のいずれの改善モードにおいてもそ うでない通常の場合と比較すると，プラスマ周辺部の電 場分布の変化により $\boldsymbol{E} \times \boldsymbol{B}$ のシアフローが発生し，エ ッジの全領域で，㕕い周波数領域にわたって静電摇動が 減少して，粒子閉じ込めが改善されることが観測されて いる. shearing rate $\sim(1 / B)\left(\mathrm{d} E_{\mathrm{r}} / \mathrm{d} r\right) \leftrightarrow 7 \times 10^{6} \mathrm{~s}^{-1}$ 程度で, 典型的な摇動のパワースペクトルの幅 $\left(-3 \times 10^{5} \mathrm{~s}^{-1}\right)$ より十分大きく，シアフローによる摇動の安定化が十分 に期待できる領域に入っている．しかしながら，シアフ ロー領域でないところでも捊動の減少が観測されている 点は興味深い。

バイアス実験では，粒子閉じ込めの向上のみが観測さ れており，エネルギー閉じ込めの向上は見られない。バ イアス実験では静龟摇動の㧕制だけが観測され，磁場摇 動は変化しないことから，先に述べた「フラズマ周辺部 では静電摇動による粒子損失が支配的であり, 静電的な 摇動によるエネルギー損失は無視できる」という結果と 合致している.

一方，EC モードやPPCDでは，磁場摇動の減少が静 電摇動の減少と同時に観測され，粒子閉じ込めのみなら ずエネルギー閉じ込めも大きく改善される（ECモード で 3 倍, PPCD では 5 倍の改善)。これらのモードでは 磁場摇動の低減が，閉し达如改善の中心的メカニズムと 考えられるので，シアフローに上る静篦採動の交定化の 役割，特にそのエネルギー閉じ巡めの[们上に与える定量 的な影響はまだはっきりしていない。

RFXにおいては，通常の運転条俳に扔いても，プラ ズマのエッジ付近に $E \times B$ のシアフローが存在するこ とが示されており，トカマク等と同様に軌道損失による イオンの選択的な撌失がその原因であると考えられてい る[60].また，先の2.4で示したように, RFXではプラ ズマの周辺部分で精子拡散係数が小さくなるが，この周 辺部分のシアフローの存在が，搪散係数の減少の原因で ある可能性が示唆されている.

最後に，MSTのEC モードでは，2つの重要な現象 が見つかッていることを指摘しておきたい。一つは， ECモードの間では，磁場搯動が つのへリカルモード に集中する㖽向，いわゆる single helical の状態に近く なることである.これは TPE-1RM20の IHT モードで も観測されており，RFXの閉じ达め向上モードでも同 様の現象が見いだされている。これについては次節で触 れる.もう一つは，軟 $\mathrm{X}$ 線の大きな崩丧を伴わないマ イルドなトロイダル磁束の生成 (small dynamo effect) が見いだされることである.これは，エネルギーの大き
な損失を伴わないダイナモ效果の存在を示唆するもので あり, 非常に重要である。この時には， $m=1$ ではなく $m=0$ の摇動が中心的な役割を演していることがわかっ ており，宫本により提案された $[20] m=0$ モードのダイ ナモ効果の存在を坚証するものであるかもしれないが， 詳しいメカニズムの解明はこれからである.

\section{5 single helical state}

単一のヘリシティを持つ MHD 的な摇動 (single helical mode)のみでも, 平均磁場に平行な電流の駆動（い からるアルファ効果）が可能であることは，以前から知 られていたが[61]，このことは，多数のモード間の非線 形的な相互作用による実効的な電場の発牛という，従来 考えられてきたタイナモ効果ではなく， single helical mode によるダイナモ効果の可能性を示唆するものと考 えることができる.

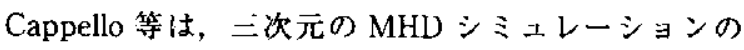
結果から [62], multi-mode の状態から quasi-single helical な楥和状態へのダイナミカルな遷移が起こるこ と，そしてこの遷移を決めるキーパラメータがプラン トル数であると主張している。ここで，プラントル数

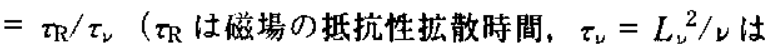
粘性による搪散時間，レはプラズマの粘性を睤量密度で 割った值， $L_{2}$ は粘性による dissipation の特徽的な長さ) である. RFX のダループはプラントル数が小さい時に は, multi-modcのダイナモ効果が㧍こり， stochasticな 磁力線構造となるが、プラントル数が人きい時には, quasi-single helical mode のダイナモ効果によって保持 される準定常的な状態が現れ，磁力線が stochasticにな る空間的な領城か狭まり（あるいは理想的な場合には磁 気面の破壊が起こらず）閉じ込めを劣化させない配位の 維持が期待できると考えている，また，Finn 等により， 電弎抵抗老持った RFPで，定常的な single helical statcの平衡が存在する叮能性が示されている[63].

RFXの実験では， $\alpha$ モードと呼ばれる閉じ込め改善 モードが見つかっており，その期間中では前後と比較し て, 磁気摇動の $m=1, n=8-9$ モードへの集中と, プ ラントル数の 5 から14への增大が同時に観测されている $[29,46]$.

先に述べた，MST とTPE-1RM20で見いだされた閉 じ込め改善モード，PPCD，EC，IHT モードのいずれ においても，開じ这めの向上している期問に，磁場摇動 が単一のトロイダルモード数 $n$ を持つ $m=1$ のモード に集中する場合が多く観測されており (Fig. 12 参照), singlc helical mode の状態に近い状態が現れることが多 
いが，上に述べたブラントル数の変化による状態の背移 との関連は必すしも明礁ではなく，その検証は今啳の源 题である。

ただし，これら4のの閉じ込め改善モード（PPCD； EC, IHT モード, $\alpha$ モード) が現れるには，1）低密 度領域，2）十分な真空容器壁のコンディショニング, 3）精菜な不整磁場の補正，4）高電子温度，5）卜口 イダ磁場の深い逆転, という共通の条件があり，また， PPCD 以外の自発的に現れる改善モードは, 䜌やかなブ ラズマ電流の減衰時期に現れるという其通吽が見つかっ ている.したがって、これらの閉じ込め收善モードを統 一的に記述する，共通なメカニズムとキーパラメータの 存在が予想されるが, 上に述べたプラントル数の変化に よる single helical stateへの遷移はその一つの候補であ るかもしれない。

\section{4. おわりに}

これまで述べてきたように，装置の大型化による分布 計測の充実と加熱人力密度の低下にともない，RFPの プラズマ閉じ迟めでは，磁場摇動による RechesterRosenbluth 型の拡散が支配的であることが明らかとな ってきた、さらにまたははっりと確定したわけではな いが，磁場採動は，フラズマパラメータの向上（特に磁 場強度と電子温度の増大）によって磁気レイノルズ数， Sが大きくなっても，当初期待されていたようには減少 していかないことを示支実呀データが得られている.

残念ながら，放電初期の $S$ が小さい段階で磁場の緩 和現象 (ダイナ飞効果) を使って RFP 配位を形成し, 配位形成後ではたとえダイナモ效果が存在しても，プラ ズマパラメータの向上（Sの増加）による磁場摇動レベ ルの低下がもたらす閉じ込め性能の们上に期待して，必 要なプラズマ閉じ込めを実現しようとする，いささか虫 の良いRFPのシナリオは, どうもうまくいきそうもな いようである。ただし，燃焼時間が千秒程度のパルス炬 が可能であるならば，配位形成後は磁場配位を自然減衰 するにまかせて, 若于のブラズマ電流分布制御を加味す ることにより, ダイナモフリーの,すなわち,

Rechester-Rosenbluth 型の拡散のない良好な閉じ迟め を実現してプラズマの燃焼を行う，パルス炉を考えるこ とはできる。

RFPの閉じ込め研究の現状を見ると，上記のような 配位の娍衰フェーズを利用する場合もそのひとつの例と して考えるとしても，現状と比較して何らかの方法で閉 じ込めを改善する方法を見いだすことが必要であると思
われるが,これまで速べてきたことから，2つの有望な 改善の方向が見えてきたということができる、一のは， 直接電流駆動を用いた，ブラズマ電流分布の制御による ダイナモモードの安定化であり，もう一つは, stochastic な磁力線構造を引き起こさない, 単一のヘリカルモー ド状態によるタイナモ効果を用いる方法である.

前者の方法は, 将来の核融合炣の定常運転の必要性を 考虑すると, 本命の方法であり, RFPにおいて今後最 も重点をおいて研究を進めていくべき課題であると考え られる.閉じ込め性能の向上に対する周辺電流の直接駆 動の有効性は, MST における PPCDの実験で, エネル ギー閉じ込め時間が 5 倍に増加したことから，京でに検 証されたと考えられる。令後の進め方としては，当面は 周巡部分の密度の低いところでのポロイダル電流駆動 を，低域混成波を用いて行ってその効果を碓かめた後， 高密度でも効事的な電流駆動が可能な速波，あるいは中 性粒子ビーム入射等を用いて, 中心部分の高密度領城を 含んだ全体的な電流駆動へと，研究を進めていくのが適 当であると思われる，ウイスコンシン人学のMST 装置 では，低域混成波を用いた電流駆動実験の準備が開始さ れており，近々実験が開始される予定である。予算の制 限等から，必要な $1 \mathrm{MW}$ の入射実験はもう少し先にな ると予想されるが，結果がどうなるか期待されるところ である.

もし今後の研究を通して，核融合炬のブラスマパラ メータ領域で使用可能な, 高刘率の電游駆動法を開発す ることができれば，ダイナモフリーで閉じ込め特性の良 い定常 RFP炉が実垷できると考えられる，逆に言えば， そのような電流駆動法がなけ扎ば，定常 RFP 如を想定 することは碓しい、ただし，たとえ通当な電流駆動法が 見つかっても，RFP炬の理想とする, Simple Fusion Reactor というコンセプトに適合できるものであるかど うかについては，十分な考慮が必要であろう。

TPE-1RM20ではIHT モード, MSTではEC モード, $\mathrm{RFX}$ では $\alpha$ モード等の, 閉じ込め改善モードが見いだ されている.これらの閣じ这め改善モードのメカニズム の解明は, 今後の重要課題であるが, もしこれらの閉し 込め改善モードが, 単一のヘリカルモードによるタイナ モ効果の存在と関係しているのであれば，この方式によ る閉じ込めの改善は, Simple Fusion Reactor というコ ンセブトに嗃合する可能性は高く，今後大いに期待のも てる方式である.実検的に現れる単一ヘリカルモードは, 今のところすべて自発的に現れたもので，この状態を再 現性よく作り出すための運転条件の設定方法はまだ確立 
していない。今後はこの点に重点を专いた研究を進め, 単一ヘリカルモードの物理の解明を通して，このモード を実現・維持するためのキーバラメータを見つけていく 必要があると思われる.

最後に，電子技術棇合研究所において最近実呀が開始 された，新しいRFP 実験装置 TPE-RXについて简単に 紹介する [64-66]. TPE-RX は, 大半径 $1.7175 \mathrm{~m}$, 小半 径 $0.45 \mathrm{~m}$, 最大目標ブラズマ電流 $1 \mathrm{MA}$, 放電持続時間 $100 \mathrm{~ms}$, プラズマ体皘 $7 \mathrm{~m}^{3}$ の大型 RFP 装置であり， RFPのプラズマ閉じ这めのメカニズム解明と，閉じ込 め性能向上の実現をその目的としている，目標エネル ギー閉じ䢋め時間は 5 - $10 \mathrm{~ms}$ であるが，この值を実 現するために，

1) プラズマに近接した二首の薄肉金属シェル（銅慗, $0.5 \mathrm{~mm}$ 厚 $\times 2)$ と一層の厚肉金属シェル（Al 製, $50 \mathrm{~mm}$ 厚) によるプラズマの安定化と不整磁場の 低減。

2）不整磁場発生の最小化とその高精度の補正（特に金 属シェルカット部)，

3 ）準定常垂直磁場によるプラズマの平衡位置制街,

4）一体型真空谷器を用いた高真空度の達成による不純 物の低滅,

5）モリブデンリミタの採用による粒子リサイクリング 制御 (低密度運転) ,

等の装置上の特徴を持っている。

TPE-RXのフラズマ閉じ迟め実験は最近開始された ばかりであり，現在のとこつ，最大ブラズマ電流〜 500 $\mathrm{kA}$ ，最長放電時問～ $85 \mathrm{~ms}\left(I_{\mathrm{p}} \sim 250 \mathrm{kA}\right)$ ，中心コードで の平均電子密度 $(0.02-0.15) \times 10^{20} \mathrm{~m}^{-3}$ 程度のプラズ マが得られている，今後は温度その他の測定を行い，上 䛉の目的の達成をめざした研究を進めていく予定であ る、また，RFやNBIによる直接電流駆動は，将来の研 究課題として华備を行っているところであるが, 当面の 閉じ込め向上の研究としては，白発的に現れる様々な閉 じ迄め改善モードに関する研究に重点を置いて実辆を進 めることを予定している，TPE-RXでは，上に述べた 装量の特幑から，先に示した閉じ込め改善モードを実現 するために必要と考えられる共通な条件，1）低密度領 娀運転，2）十分な真空宽器壁のコンディショニング,

3）精密な不整磁場の補正，4）高電子温度，5）卜口 イダル磁場の深い逆転，6）爰やかなプラズマ電流の滅 衰，を比較的容易に満たすことが订能であり，今後の実 験の進展により，これら閉じ込め收善モードのメカニズ ム，その他の理解が進むと期待るれる。
RFP のプラズマ閉じ込め研究の現状を一口でまとめ ると，現状のままスケールアップ等で進んでいけば，核 融合如への道が開けるというバラ色の状態ではなく，閉 じ这め性能向上のための何らかの手法が必要であるが, 最近の研究によりこの向上のための方法が見えてきた， すなわち，トンネルの出口の明かりが見えてきた状態で あるということができよう。

\section{謝辞}

このレビューに載せた図面を快く提供してくださると ともに，貫重な議論をしていただいた，MSTおよび RFX グループのカに感榭いたします。

\section{考支献}

[1] H.A.B. Bodin and A.A. Newton, Nucl. Fusion 20 , 1255 (1980).

[2] H.A.B. Bodin, Nucl. Fusion 30, 1717 (1990).

[3] 平野洋一, 小川 潔 : 㤥壁合研究 65, 601 (1991).

[ 4 ] T. Ohkawa et al., Nucl. Fusion 20, 1464 (1980).

[5] T. Shimada et al., Proc. 12th Int. Conf. Plasma F'hys. Contol. Fusion Research, IAEA, Nice (1988) Vol.2, p.457.

[6] Y. Hirano, Y. Maejima et al., Nucl. Fusion 36, 721 (1996).

[ 7 ] Y. Yagi, P.R. Brunsell et al., Proc. 15th Int. Conf. Plasma Phys. Contol. Fusion Research, IAEA, Seville (1994) Vol.2, p.415.

[8] A. Buffa and RFX Team, Proc. 23rd EPS Conf. Contol. Fusion and Plasma Phys. Kiev (1996) part2. p. 629

[ 9 ] J.S. Sarff, N.E. Lanier et al., Phys. Rev. Lett. 78, 62 (1997).

[10] J.W. Connor and J.B. Taylor. Phys. Fluids. 27, 2676 (1984).

[11] A. Bhattacharjee and E. Hameiri, Phys. Fluids. 31. 1153 (1988).

[12] J.N. Dimarco, Los Alamos Report, LA-UR REVISED-88-3375 (1988).

[13] J.B. Taylor. Phys. Rev. Lett. 33, 1139 (1974).

[14] 政宗貞男, 平野洋一：核融合研究 68, 268 (1992).

[15] K. Hattori, Y. Hirano et al., Phys. Fluids. B 3, 3111 (1991).

[16] P.R. Brunsell, Y. Yagi et al., Phys. Fluids. B 5, 885 (1993).

[17] Y. Hirano, Y. Yagi et al., Plasma Phys. Contol Fusion 39 (5A) , A393 (1997).

[18] A.B. Rechester and M.N. Rosenbruth, Phys. Rev. Lett. 40, 38 (1978). 
[19] Z.G. An, P.H. Diamond et al., Proc. 10th Int. Conf. Plasma Phys. Contol. Fusion Research, IAEA. London (1984) Vol.2, p.231

[20] K. Miyamoto, Plasma Phys. Control. Fusion 30, 1493 (1988).

[21] 服部健一, 平野洋一他：核融合研究 69，1507 (1993).

[22] P.N. Yughmanov, T. Takizuka et al., Nucl. Fusion 30. 1999 (1990).

[23] Y. Yagi. Y. Hirano et al., Fusion Technol, 27. 301 (1995).

[24] M.R. Stoneking, N.E. Lanier et al., Phys. Plasmas 4, 1632 (1997).

[25] K. Miyamoto, submitted to J. Plasma Fusion Res.

[26] R.N. Dexter, D.W. Kerst et al., Fusion Technol. 19. 131 (1991).

[27] G. Malesani. G. Rostagni. Proc. 14th Symp. Fusion Technollogy, Avignion (1986) Vol.1, p.173

[28] 平野洋一- : 電気学会論文誌 A. 118, 97 (1998).

[29] R. Bartiromo, A. Buffa et al., to be published in Proc. 17th Int. Conf. Fusion Energy, IAEA, Yokohama (1998) IAEA-CN-69/EX4/3.

[30] D. Gregoratto, L. Garzotti et al., Nucl. Fusion 38. 1199 (1998)

[31] V. Antoni, P. Martin et al., to be published in Proc. 17th Int. Conf. Fusion Energy, IAEA, Yokohama (1998) IAEA-CN-69/EXP3/15.

[32] Y. Yagi, T.J. Baig et al., Nucl. Fusion 37, 1775 (1997).

[33] G. Fiksel, A.F. Almagri et al., to be published in Proc. 17th Int. Conf. Fusion Energy, IAEA, Yokohama (1998) IAEA-CN-69/EX4/5.

[34] T.D. Rempel, C.W. Spragins et al., Phys. Rev. Lett. 67, 1438 (1991).

[35] M.R. Stoneking, S.A. Hokin et al., Phys. Rev, Lett. 73. 549 (1994).

[36] V. Antoni, R. Cavazzana et al., Phys. Rev. Lett. 80, 4185 (1998).

[37] P.R. Brunsell. Y. Maejima et al., Phys. Plasmas I, 2297 (1994).

[38] P.W. Terry. G. Fiksel el al., Phys. Plasmas 3, 1999 (1996).

[39] H. Ji, H. Toyama, K. Miyamoto et al, Phys. Rev. Lett. 67, 62 (1991).

[40] G. Fiksel, S.C. Prager et al., Phys. Rev. Lett 72 , 1028 (1994).

[41] N. Mattor, Phys. Plasmas 3, 1578 (1996).

[42] J. La Haye, T.N. Carlstrom et al., Phys. Fluids 27, 2576 (1984).

[43] M.R. Stoneking, J.T. Chapman et al., Phys. Plasmas 5, 1004 (1998).

[44] F. Najmabadi. R.W. Conn et al., Joint Report of Uni- versity of California Los Angeles, GA Technologies Inc.. Los $\Lambda$ lamos National Laboratory and Rensselaer Polytech. Institute, UCLA-PPG-1100 (1987).

[45] G. Fiksel, Plasma Sources Sci. Technol. 5. 78 (1996).

[46] P. Martin, to be published in Plasma Phys. Contol. Fusion.

[47] K. Hattori, Y. Ilirano et al., Fusion Technol. 29, 1619 (1995).

[48] 服部健一, 平野洋一他：電子技術総合研究所竟報 57. 23 (1993).

[49] S. Shïna, Y. Kondoh et al., Nucl. Fusion 34. 1473 (1994).

[50] E. Uchimoto, M. Cekic et al., Phys. Plasmas 1, 3517 (1994).

[51] J.S. Sarff, A. Hokin et al., Phys. Rev. Lett. 72, 3670 (1994).

[52] T. Bolzonella. S. Martini et al., Proc. 24th EPS Conf. Cont. Fusion and Plasma Phys. Berchtesgaden, (1997) part 1, p.321.

[53] D.C. Robinson, Nucl. Fusion 18, 939 (1978).

[54] R.B. Howell, J.C. Ingraham et al., Phys. Fluids. 30, 1828 (1987).

[55] Y. Hirano, Y. Maejima et al., Proc. 16th Int. Conf. Fusion Energy, IAEA, Montreal (1996) Vol.2, p.95.

[56] D.C. Robinson and R.E. King, Proc. 3rd Int. Conf. Plasma Phys. Cont. Fusion Research, IAEA, Novosibirsk (1968) Vol.1, p.263

[57] B.E. Chapman, A.F. Almagri et al., Phys. Plasmas 5. 1848 (1998).

[58] B.E. Chapman, C.S. Chiang et al., Phys. Rev. Iett. 80. 2137 (1998).

[59] D. Craig. A.F. Almagri et al., Phys. Rev. Lett. 79. 1865 (1997).

[60] V. Antoni et al., Phys. Rev. Letters 79, 4814 (1997).

[61] H.K. Moffatt, Magnetic Field Generation in Electrically Conductive Fluid (Cambridge University Press, Cambridge, 1978) Sec. 7.7.

[62] S. Cappello and R. Paccagnella. Phys. Fluids. B 4. 611 (1992).

[63] J.M. Finn, R. Nebel and C. Bathke, Phys Fluids B 4, 1262 (1992).

[64] Y. Yagi, Y. Maejima et al., Proc. ICPP/25th EPS Conf. Cont. Fusion and Plasma Phys., Prague, (1998) 22C, p.882.

[65] Y. Yagi et. al., Fusion Technol. (Proc. of the 20th Symposium on Fusion Technology SOFT. Marseilles 1998) Vol.1, p.609.

[66] Y. Hirano, T. Shimada et al., to be published in Proc. 17th Int. Conf. Fusion Energy, IAEA. Yokohama (1998) IAEA-CN-69/EX4/4. 